\title{
Genome Editing with Engineered Nucleases in Economically Important Animals and Plants: State of the Art in the Research Pipeline
}

\author{
Tereza Sovová1*, Gerard Kerins ${ }^{2}$, Kateřina \\ Demnerováa ${ }^{3}$ Jaroslava Ovesná ${ }^{1}$
}

${ }^{1}$ Crop Research Institute, Department of Molecular Genetics, Drnovská 507, 16106 Prague, Czech Republic.

${ }^{2}$ Animal and Plant Health Agency, Genetic Modification Inspectorate, Sand Hutton, York, YO41 1LZ, United Kingdom.

${ }^{3}$ University of Chemistry and Technology, Department of Biochemistry and Microbiology, Technická 5, 16628 Prague, Czech Republic.

*Corresponding author: mail@terezasovova.cz

DOI: http://dx.doi.org/10.21775/cimb.021.041

\begin{abstract}
After induced mutagenesis and transgenesis, genome editing is the next step in the development of breeding techniques. Genome editing using site-directed nucleases - including meganucleases, zinc-finger nucleases (ZFNs), transcription activator-like effector nucleases (TALENs), and the CRISPR/Cas9 system - is based on the mechanism of double strand breaks. The nuclease is directed to cleave the DNA at a specific place of the genome which is then repaired by natural repair mechanisms. Changes are introduced during the repair that are either accidental or can be targeted if a DNA template with the desirable sequence is provided. These techniques allow making virtually any change to the genome including specific DNA sequence changes, gene insertion, replacements or deletions with unprecedented precision and specificity while being less laborious and more straightforward compared to traditional breeding techniques or transgenesis. Therefore, the research in this field is developing quickly and, apart from model species, multiple studies have focused on economically important species and agronomically important traits that were the key subjects of this review. In plants, studies have been undertaken on disease
\end{abstract}

resistance, herbicide tolerance, nutrient metabolism and nutritional value. In animals, the studies have mainly focused on disease resistance, meat production and allergenicity of milk. However, none of the promising studies has led to commercialization despite several patent applications. The uncertain legal status of genome-editing methods is one of the reasons for poor commercial development, as it is not clear whether the products would fall under the GMO regulation. We believe this issue should be clarified soon in order to allow promising methods to reach their full potential.

\section{Introduction}

The effort to improve animals and plants used for food production is as old as agriculture itself. For thousands of years, the genetic basis of domesticated species has been changed by selecting the best progeny to improve desirable characteristics, such as yield and disease resistance, in subsequent generations. Since the discovery of Mendel's laws and the understanding of basic principles of heredity, deliberate selection and crossing of best performing individuals has been applied as a basic breeding strategy. With scientific and technological development, innovative techniques were increasingly applied in the breeding process such as induced mutagenesis or tissue cultures (Fichtner et al., 2014; Puchta and Fauser, 2014; Rinaldo and Ayliffe, 2015). In plants, the use of physical and chemical mutagens has yielded many novel varieties; the FAO/IAEA Mutant Variety Database contains almost 3200 officially released mutant varieties from 214 different plant species (http:// mvd.iaea.org/). For example, cv. Diamant - a short-straw barley mutant of cv. Valticky obtained with X-ray treatment - has been widely used in malting barley breeding (Ovesná et al., 2010). However, the randomness of thus obtained mutations and the successive time-consuming screening for appropriate mutants with desirable 
traits limit the use of such methods (Puchta and Fauser, 2014). Since the 1990s, thanks to the previous discovery of the structure and function of DNA, breeding techniques have been complemented with transgenic approaches where recombinant genes obtained from different organisms are inserted in the genome of an acceptor organism to obtain a desired phenotype (such as disease- or pathogenresistance in crops, and meat production or decreased allergenicity in animals) thus forming so-called genetically modified organisms [GMOs; Fichtner et al. (2014), Ovesná and de Vries (2005)]. However, the transgene insertion site is still unpredictable. Therefore, if inserted in an undesirable location, the change in the DNA sequence can have unintended effects and produce organisms with undesirable traits or low survival rates; which has been observed most frequently in animals (Liu et al., 2013; Miao et al., 2013). Moreover, concerns have been raised over the effects of GMOs on human health or the environment (Notarnicola et al., 2012; Van Boxstael et al., 2013). Thus, the perception of the GMOs by the general public is rather reserved resulting in strict regulation in certain countries and regions, e.g. the European Union (EU). The market launch of a GMO product can therefore be very difficult and resource hungry (Bruce et al., 2013; Lusser and Davies, 2013). There has therefore been a need for different genome-modifying techniques that would allow a more precise and speedy generation of new organisms, and that would at the same time require a less extensive changes to the DNA (Bruce et al., 2013; Puchta and Fauser, 2014). This is perceived to have become more urgent with the recent unprecedented growth of the world population and global climate change that challenge the current agricultural practices (Bruce et al., 2013; Fichtner et al., 2014).

The past decade has seen the discovery of more sophisticated and elegant methods for DNA modifications that could meet this need (Bruce et al., 2013). The latest addition to the growing list of genome-editing techniques is an approach using engineered nucleases that includes four methods using site-specific or site-directed nucleases (SDNs): meganucleases (MNs), zincfinger nucleases (ZFNs), transcription activatorlike effector nucleases (TALENs), and the CRISPR/Cas9 system (clustered regularly interspaced short palindromic repeats/CRISPR associated genes). The techniques using SDNs exploit natural DNA-editing mechanisms and, when used and designed effectively, are able to generate almost any desired DNA modification ranging from substituting a single nucleotide to deleting a large DNA segment (Puchta and Fauser, 2014; Petersen and Niemann, 2015a). Due to the very promising anticipated applications and a relatively straightforward design, the research in SDNs has been developing quickly and hundreds of studies have been published so far. Even though a large majority of the studies focus on model organisms and in vitro cultures, some also address economically important organisms, such as rice or cattle (Urnov et al., 2010; Belhaj et al., 2013; Liu et al., 2013). In this review, we give an overview of studies carried out using such organisms with focus on agronomically important traits and the outlook on market launch of such modified organisms.

\section{Site-directed nucleases: methods and applications}

All of the SDN techniques use the same basic mechanism of double strand breaks (DSBs). The nucleases are designed to recognize a specific DNA locus and cleave the DNA. The DSBs are naturally occurring deleterious DNA lesions and living organisms have developed mechanisms to repair them (Curtin et al., 2012; Rinaldo and Ayliffe, 2015). Non-homologous end joining (NHEJ) is the main pathway the cells use to repair DSBs and involves the exposed DNA ends being directly reconnected. Since NHEJ is error prone, the repair is often associated with insertions or deletions (together called indels) of one or more nucleotides (Harrison et al., 2014; Rinaldo and Ayliffe, 2015). If the DSB creates overhangs (i.e. the two strands of DNA do not break at the same point), the NHEJ can also enable the introduction of a DNA template if the corresponding overhang on the other strand is compatible (Bortesi and Fischer, 2015). The second mechanism, homologous recombination $(\mathrm{HR})$, is based on a template homologous to the sequence surrounding the DSB. The template is present in the chromosome in case of a naturally occurring HR; however, if an external template is delivered, the HR can be used to make custom changes to the genome including insertions of an exogenous DNA sequence (Harrison et al., 2014; Belhaj et al., 2015; Bortesi and Fischer, 2015). Due to the provided template, the change made by HR is usually exact (Belhaj et al., 2015); however, compared to NHEJ, it occurs 
much less often and various strategies have to be applied to increase the efficiency, e.g. overexpression of proteins or negative selection markers (Bortesi and Fischer, 2015; Petersen and Niemann, 2015b). There are three ways of using SDNs that differ in the presence and/or type of the repair template (Podevin et al., 2012; Araki et al., 2014; Hartung and Schiemann, 2014). In the case of SDN-1, no template is provided and the edition involves a random mutation of one or a few base pairs. In the case of SDN-2, the template provided is homologous but not identical to the target sequence and can introduce small specific changes to the sequence. In the case of SDN-3, a large DNA template is involved that could be an entire gene that may be cis-, intra-, or transgenic (Podevin et al., 2012; Araki et al., 2014; Hartung and Schiemann, 2014). Since the recognition domains of the nucleases are very long (typically 18-40 bp), the techniques offer an unprecedented specificity and precision of the genome changes (Fichtner et al., 2014; Rinaldo and Ayliffe, 2015). However, the techniques require a detailed knowledge of the structure of the chromosome and the function of the different genes, which is not available for all organisms and desired traits (Fichtner et al., 2014). Moreover, even with the high specificity of the techniques, the nuclease might still cleave additional sites that are similar to the target sites potentially causing unwanted mutations, known as off-target effects, which is one of the issues of SDNs in general and should be carefully monitored (Carlson et al., 2013; Fichtner et al., 2014; Petersen and Niemann, 2015b). Software tools are being developed to minimize the probability of off-target effects (Naito et al., 2014; Xie et al., 2014), however, the production of an organism with the desired mutation might still require a screening process to eliminate undesirable traits. Nonetheless, compared to conventional transgenesis or induced mutagenesis, the SDNs provide a much less laborious and more straightforward approach (Lusser and Davies, 2013; Araki and Ishii, 2015).

There are a number of reviews focusing on the principle of the different SDNs, see for example Petersen and Niemann (2015a), Rinaldo and Ayliffe (2015), or Voytas (2013). Here, we provide only a brief explanation of the SDNs and their possible applications.

\section{Meganucleases}

MNs (also called homing or rare-cutting endonucleases) were the first of the SDNs used to produce genome manipulations via DSBs (Puchta and Fauser, 2014; Petersen and Niemann, 2015b). The MNs are naturally occurring endonucleases that identify specific DNA sequences and several hundreds of different MNs have been recognized so far in eukaryotes, bacteria and archea. The advantage of MNs is their small size, thus, making them suitable to a majority of delivery methods (Rinaldo and Ayliffe, 2015). However, the a priori fixed target sites of the MNs are not common and the customization of the sites is very challenging and time-consuming due to the DNA-binding domain not being clearly separated from the catalytic domain, hence customisation may compromise the enzymatic activity (Curtin et al., 2012; Liu et al., 2013; Rinaldo and Ayliffe, 2015). Therefore, the potential of MNs to be commonly used in genome editing is limited (Puchta and Fauser, 2014).

\section{Zinc finger nucleases}

The ZFNs are composed of two independent regions: a recognition domain of zinc fingers each identifying a nucleotide triplet of the target DNA sequence and a non-specific nuclease, called Fokl, creating the DSB (Harrison et al., 2014; Rinaldo and Ayliffe, 2015). Since the nuclease needs to dimerize in order to be active, the ZFNs are used in pairs. Like MNs, ZFNs are also relatively small and the design of the recognition domain is more straightforward compared to MNs by simply combining different zinc fingers (Rinaldo and Ayliffe, 2015). However, ZFNs are more prone to off-target effects and have shown to have negative effects on cell proliferation (He et al., 2014; Puchta and Fauser, 2014; Ousterout et al., 2015).

\section{Transcription activator-like effector nucleases}

Similarly to ZFNs, TALENs are composed of two independent parts. The first part originates from the transcription activator-like effectors (TALEs), a group of proteins first discovered in plant bacterial pathogens of the genus Xanthomonas (Bonas et al., 1989). During the bacterial infection, TALEs are transported directly into the plant cells where they bind to specific DNA sequences and modulate the expression of plant genes to promote the bacterial pathogenesis (Curtin et al., 2012; Puchta and Fauser, 2014; Petersen and Niemann, 2015b; Rinaldo and 
Ayliffe, 2015). After the DNA binding codes of the natural TALEs have been identified, it is now possible to design artificial TALEs targeting any desired DNA sequence in both plants and animals (Petersen and Niemann, 2015b; Rinaldo and Ayliffe, 2015). The TALEs are then fused with a Fokl nuclease domain which again creates the DSB. Compared to ZFNs, the design is more straightforward, and longer recognition sites increase the specificity of TALENs making it less prone to off-target mutations and also less likely to cause deleterious effects (Puchta and Fauser, 2014; Petersen and Niemann, 2015b). When used in groups, TALENs allow multiplexing, also called gene stacking (i.e. insertion of multiple genes at once). A slight disadvantage is the increased size which makes the delivery of TALENs to cells more challenging compared to ZFNs (Fichtner et al., 2014).

\section{The CRISPR/Cas9 system}

The CRISPR/Cas9 system is part of the adaptive defence system in prokaryotes first discovered in E. coli (Ishino et al., 1987; Jansen et al., 2002). It consists of guide RNAs that direct a nuclease, e.g. Cas9, which is utilised by bacteria such as Streptococcus pyogenes in their adaptive immunity systems to recognize and cleave a specific site in the target DNA (Puchta and Fauser, 2014; Rinaldo and Ayliffe, 2015). The CRISPR/Cas9 system is the most recent of the SDNs (Boettcher and McManus, 2015); the design is straightforward and can be accomplished quickly as the only part that needs redesign is the guide RNA (Puchta and Fauser, 2014). The CRISPR/Cas9 system also allows multiplexing to generate organisms with multiple mutations or large chromosomal deletions (Belhaj et al., 2015). The CRISPR/Cas9 system and TALENs are the most promising SDNs.

\section{Applications of site-directed nucleases}

The precision and specificity of the SDNs allows modification of any location within the genome and virtually any desired modification. The most common and simple DNA mutation is the gene knock-out via NHEJ. The function of a gene is disrupted by introducing an error in the gene sequence most often within the open reading frame of the target gene creating early frame shift mutations or premature stop codons (Boettcher and McManus, 2015; Bortesi and Fischer, 2015). It is possible to designate the target location but the random nature of NHEJ prevents, in most cases, any control over the nature of the mutation (Chen and Gao, 2013; Voytas, 2013; Rinaldo and Ayliffe, 2015). Therefore to perform a specific DNA change, it is necessary to provide a template of the desired DNA sequence. Thus, it is possible to perform specific modifications to a DNA sequence, such as gene insertions, replacements or deletions [including transgenes; Chen and Gao (2013), Rinaldo and Ayliffe (2015)]. Moreover, when using TALENs or CRISPR/Cas9, it is possible to perform gene stacking to introduce multiple genes in one locus; this increases the stability and facilitates inheritance of thus obtained traits (Ainley et al., 2013; D'Halluin et al., 2013). If using multiple nucleases at once, it is also possible to perform large DNA deletions (allowing removal of entire gene regulatory networks), inversions, or translocations (Chen and Gao, 2013). It is also possible to control the expression of the genes of interest by targeting the binding sites for natural transcription factors (Li et al., 2012).

\section{Site-directed nucleases for improvement of economically important plants}

The application of SDNs in plants is developing quickly and there is a large number of studies dealing with model plants such as Arabidopsis thaliana (Cermak et al., 2011; Antunes et al., 2012; de Pater et al., 2013; Jiang et al., 2013), Nicotiana tabacum (Zhang et al., 2013; Gao et al., 2015) or Nicotiana benthamiana (Li et al., 2013b). The studies involving economically important plants are summed up in Table 1. The majority of published studies have focused on the more feasible and promising TALENs and CRISPR/Cas9 systems. Many studies have dealt with rice which, apart from being an important crop species and source of staple food across the globe, is also used as a model species due to its genome size. However, in general, only a minority of studies published so far have been aimed at specific and agronomically beneficial traits; these can be divided into three groups: (1) disease resistance, (2) nutrient use, and (3) nutritional value.

Development of disease-resistant plant varieties is highly desirable. Several resistant varieties have been successfully developed using transgenesis, such as the ringspot virus-resistant papaya (Fitch et al., 1992) or the fungusresistant Innate ${ }^{\mathrm{TM}}$ Russet Burbank Potato (Osusky et al., 2000). The cultivation of diseaseresistant plants has the potential to reduce the 


\begin{tabular}{|c|c|c|c|c|c|}
\hline Technique & Type of transformation & Species & Target gene & Target trait & Reference \\
\hline \multirow[t]{3}{*}{ MNs } & Gene knock-out & maize & $\lg 1$ & - & Gao et al., 2010 \\
\hline & & & $m s 26$ & - & Djukanovic et al., 2013 \\
\hline & Gene stacking & cotton & transgene (epsps, hppd) & herbicide tolerance & D'Halluin et al., 2013 \\
\hline \multirow[t]{10}{*}{ ZFNs } & Gene knock-out & apple & transgene (gus) & - & Peer et al., 2015 \\
\hline & & fig & transgene (gus) & - & Peer et al., 2015 \\
\hline & & petunia & transgene (DsRed2) & - & Marton et al., 2010 \\
\hline & & maize & ipk1 & phosphorus metabolism & Shukla et al., 2009 \\
\hline & & soybean & $d c l$ & & Curtin et al., 2011 \\
\hline & Gene knock-in & maize & transgene (pat) & herbicide tolerance & Shukla et al., 2009 \\
\hline & & & transgene (pat) & herbicide tolerance & Kumar et al., 2015 \\
\hline & & rice & transgene (gus) & - & Cantos et al., 2014 \\
\hline & Gene stacking & maize & transgene (pat, aad1) & herbicide tolerance & Ainley et al., 2013 \\
\hline & Gene expression control & rapeseed & kasii & oil content & Gupta et al., 2012 \\
\hline \multirow[t]{6}{*}{ TALENs } & Gene knock-out & barley & transgene $(g f p)$ & - & $\begin{array}{l}\text { Gurushidze et al., 2014, } \\
\text { Budhagatapalli et al., } 2015\end{array}$ \\
\hline & & & PAPhy_a & - & Wendt et al., 2013 \\
\hline & & maize & $p d s, i p k 1 a, i p k$, mrp4 & phosphorus metabolism & Liang et al., 2014 \\
\hline & & & g/2 & - & Char et al., 2015 \\
\hline & & potato & als & - & Nicolia et al., 2015 \\
\hline & & & VInv & reducing sugars content & Clasen et al., 2015 \\
\hline \multirow[t]{11}{*}{ TALENs } & Gene knock-out & rapeseed & fri & - & Sun et al., 2013 \\
\hline & & rice & dep1, ckx2, badh2, sd1 & - & Shan et al., 2013a \\
\hline & & & badh2 & fragrance & Shan et al., 2015 \\
\hline & & soybean & fad2-1a, fad2-1b & oil content & Haun et al., 2014 \\
\hline & & & pds & - & Du et al., 2016 \\
\hline & & tomato & pro & - & Lor et al., 2014 \\
\hline & & wheat & mlo & disease resistance & Wang et al., 2014 \\
\hline & Gene knock-in & wheat & transgene $(g f p)$ & - & Wang et al., 2014 \\
\hline & & tomato & ant1 & - & Cermák et al., 2015 \\
\hline & Gene expression control & rice & sweet14 & disease resistance & Li et al., 2012 \\
\hline & $\begin{array}{l}\text { Large DNA segment } \\
\text { deletion }\end{array}$ & rice & badh2 & - & Shan et al., 2013b \\
\hline \multirow[t]{11}{*}{ CRISPR/Cas9 } & Gene knock-out & maize & $p d s, i p k 1 a, i p k$, mrp4 & phosphorus metabolism & Liang et al., 2014 \\
\hline & & lettuce & bri1 & - & Woo et al., 2015 \\
\hline & & poplar & $p d s$ & - & Fan et al., 2015 \\
\hline & & potato & iaa2 & - & Wang et al., 2015b \\
\hline & & rice & roc5, spp, ysa & - & Feng et al., 2013 \\
\hline & & & sweet 11 , sweet14 & disease resistance & Jiang et al., 2013 \\
\hline & & & cao1, lazy1 & - & Miao et al., 2013 \\
\hline & & & pds, badh2, mpk2 & - & Shan et al., 2013b \\
\hline & & & $m p k 5$ & disease resistance & Xie and Yang, 2013 \\
\hline & & & $\begin{array}{l}\text { pds, pms3, epsps, derf1, msh1, } \\
\text { myb5, myb1, roc5, spp, ysa }\end{array}$ & - & Zhang et al., 2014b \\
\hline & & & bel & - & Xu et al., 2014 \\
\hline \multirow[t]{14}{*}{ CRISPR/Cas9 } & Gene knock-out & rice & AOX1 family, bel & - & Xu et al., 2015 \\
\hline & & & $p d s, d l$ & - & Mikami et al., 2015 \\
\hline & & & aoc, phyb, p450, dwd1 & - & Woo et al., 2015 \\
\hline & & sorghum & transgene $(D s R e d 2)$ & - & Jiang et al., 2013 \\
\hline & & soybean & $\begin{array}{l}\text { transgene }(g f p), 07 g 14530, \\
11 g 07220, \mathrm{mir}\end{array}$ & - & Jacobs et al., 2015 \\
\hline & & & $06 \mathrm{~g} 14180,12 \mathrm{~g} 37050,08 \mathrm{~g} 02290$ & - & Sun et al., 2015 \\
\hline & & & transgene (bar), fei2, shr & - & Cai et al., 2015 \\
\hline & & & $p d s$ & - & Du et al., 2016 \\
\hline & & $\begin{array}{l}\text { sweet } \\
\text { orange }\end{array}$ & pds & - & Jia and Wang, 2014 \\
\hline & & tomato & ago7 & - & Brooks et al., 2014 \\
\hline & & & rin & - & Ito et al., 2015 \\
\hline & & wheat & inox, pds & - & Upadhyay et al., 2013 \\
\hline & Gene knock-in & tomato & $\begin{array}{l}\text { mlo } \\
\text { ant1 }\end{array}$ & dis & $\begin{array}{l}\text { Shan et al., 2013b } \\
\text { Čermák et al., } 2015\end{array}$ \\
\hline & $\begin{array}{l}\text { Large DNA segment } \\
\text { deletion }\end{array}$ & rice & $\begin{array}{l}\text { labdane-related diterpenoids } \\
\text { production genes }\end{array}$ & - & Zhou et al., 2014 \\
\hline
\end{tabular}

use of pesticides and other agrochemicals that often have a negative effect on the environment and may adversely affect the quality of the final product in terms of human health. Moreover, the development of such varieties is likely to have positive economic effects due to increased yield and better profit margins due to the potential cost savings in reduced agrochemical use. In the
USA alone, crop losses due to plant pathogens are worth $\$ 33$ billion per year (Pimentel, 2011) despite the use of almost 500,000 tonnes of pesticides per year (Pimentel and Burgess, 2014). For example, bacterial blight is the most important disease in rice (Dossa et al., 2015); the resulting yield loss ranges between $20 \%$ and $30 \%$ and, in the case of a serious infection, it 
can increase up to $80 \%$ causing substantial economic loss (Khan et al., 2014). SDNs have been used to create bacterial blight-resistant rice by targeting the sweet genes involved in bacterial blight susceptibility in rice using TALENs (Li et al., 2012) and CRISPR/Cas9 (Jiang et al., 2013). The sweet genes encode sucrose transporters (sweet stands for Sugars Will Eventually be Exported Transporters); during infection, the pathogen takes over the gene promoter with its own TALEs to activate the gene in order to satisfy its nutritional needs. In the study by Li et al. (2012), a pair of TALENs was designed that targeted the effector-binding elements for the pathogen's TALEs within the promoter of the sweet14 gene. Thus the pathogen's TALEs were not able to activate the gene which, however, still maintained its developmental function. Plants with homozygous monoallelic or heterozygous biallelic mutations, effectively conferring bacterial blight resistance, were created in the study and the trait was inherited in subsequent generations; the majority of the obtained mutations were small deletions.

Powdery mildew, one of the most important crop pathogens worldwide usually leading to up a $50 \%$ loss in yield (Cao et al., 2011), was the subject of a study by Wang et al. (2014) who attempted to obtain a resistant variety of wheat by targeting the mlo (mildew locus $O$ ) gene coding for proteins repressing defence against the disease. A pair of TALENs was created that targeted a region in exon 2 of all three homoeologs of the gene, creating mainly small deletions. Homozygous mutation of all three homoeologs was necessary to confer effective and heritable mildew resistance. The mlo gene was also targeted in wheat using CRISPR/Cas9 (Shan et al., 2013b). Xie and Yang (2013) successfully targeted the mitogen-activated protein kinase 5 (mpk5) gene in rice using CRISPR/Cas9. The mpk5 gene acts as a negative regulator of rice defence response and its knock-out could improve the general disease resistance of rice.

The uptake of nutrients and their efficient use constitute another important agricultural trait. If the metabolism of plants can be altered such that they use nutrients more efficiently, this could lead to an increase in yield. Such metabolic alterations may also allow less fertile soils to be more efficiently cultivated. As a result, such improved crops might require less fertilizer and/ or fewer crop treatments, which may have positive economic and environmental effects (White and Brown, 2010). Phosphorus and nitrogen are the major limiting nutrients that need to be provided in fertilizers. Unlike nitrogen, which is abundant in the atmosphere, the phosphorus for fertilizer production is available only in the form of phosphatic minerals which, due to the rapidly growing world population and associated increases in fertilizer consumption, are being quickly depleted. The phosphorus metabolism in both plants and animals is quickly becoming an important issue. Moreover, increased phosphorus concentration in surface waters from surface runoff or manure has detrimental effects on aquatic ecosystems (Shukla et al., 2009; Liang et al., 2014). Therefore, creating plants and animals that would metabolize phosphorus more efficiently is of great interest. Using transgenesis, this issue was approached for example by Spencer et al. (2000) who have created a low phytate corn intended as pig feed. Shukla et al. (2009) and Liang et al. (2014) have used ZFNs, and TALENs and CRISPR/Cas9, respectively, to target the inositol-1,3,4,5,6-pentakisphosphate 2-kinase 1 (ipk1) gene controlling synthesis of phytic acid in maize. Phytic acid represents the majority of phosphorus present in maize seeds used as feed, however, phytic acid is not metabolized by animals and is secreted causing environmental pollution. By knocking out the ipk1 gene, the content of phytic acid in the seeds is reduced. Shukla et al. (2009) have used ZFNs to disrupt the exon 2 region of the gene and subsequently to knock-in the phosphinothricin acetyl transferase (pat) transgene conferring glufosinate herbicide tolerance to that locus. Subsequent analysis of seeds of $\mathrm{T}_{2}$ generation plants revealed reduced levels of phytic acid. The knock-in of the pat gene thus effectively and hereditarily mutated the ipk1 and, moreover, simultaneously conferred herbicide resistance. Furthermore, no off-target effects were observed. Liang et al. (2014) have also successfully introduced small deletions and insertions into the ipk gene using TALENs and CRISPR/Cas9 that proved to be heritable in the case of the TALENs-mediated mutation.

Improvement of the nutritional value of agricultural end-products is another important goal and has been intensively studied using conventional breeding and transgenesis. Possible improvements include resulting 
products that are more amenable to processing or are more attractive for consumers due to the increased content of human health-promoting substances. Examples of the transgenic approach include Golden rice with provitamin A content (Beyer et al., 2002) or soybean with decreased $\alpha$-linolenic fatty acid content (Flores et al., 2008). Seed oil composition in soybean was also the subject in the study by Haun et al. (2014) who have used TALENs to knock-out the fatty acid desaturase 2 (fad2) genes. The enzyme catalyzes the conversion of the monounsaturated oleic acid to the polyunsaturated linoleic acid. Four TALENs were designed that targeted the start codon of both of the alleles of fad 2. Small deletions on both of the alleles were achieved which led to a heritable substantial decrease in the oleic acid production. Another trait studied is the content of reducing sugars (e.g. monosaccharides such as glucose and fructose) that accumulate in vegetables such as potatoes during storage especially in cold temperatures. During processing at high temperatures, those sugars transform into bitter dark-pigmented products that decrease the organoleptic characteristics of the products. Moreover, the sugars react with amino acids forming acrylamide, a potential carcinogen (De Wilde et al., 2005). Clasen et al. (2015) have used TALENs to knock out the vacuolar invertase gene (VInv) in potatoes. This gene encodes an enzyme breaking down sucrose to glucose and fructose. Eighteen plants were obtained that bore the desired mono- or biallelic mutations. Analysis of the tubers from biallelic knock-out plants showed undetectable levels of reducing sugars; furthermore, processed potato chips had reduced levels of acrylamide. Shan et al. (2015) have focused on fragrance in rice. Fragrant rice, such as the Indian Basmati or Thai Jasmine, is much more popular and valuable than the conventional nonfragrant rice. The distinct fragrance of the rice is caused by presence of many volatile compounds, such as 2-acetyl-1-pyrroline. The gene responsible for 2-acetyl-1-pyrroline biosynthesis is the betaine aldehyde dehydrogenase 2 (badh2). The naturally fragrant rice has multiple mutations at different locations of the gene which results in the gene's malfunction. Shan et al. (2015) have introduced artificial mutations to the genes using TALENs in nonfragrant rice. Several homo- and heterozygous mutant plants were created with mainly small deletions. The mutations were faithfully transferred in subsequent generations and the grains of the T1 generation of both homo- and heterozygous plants showed increased 2acetyl-1-pyrroline content comparable to naturally fragrant rice.

Multiple studies have looked at model transgenes, such as the fluorescent dsRed2 gene (Marton et al., 2010; Jiang et al., 2013), and several have also attempted to create transgenic plants with useful traits. Traditional transgenic techniques cannot control the DNA locus where the transgene is incorporated which is, however, possible when using SDNs; this facilitates the insertion and functionality of the transgene. In the already mentioned study by Shukla et al. (2009), transgenic maize plants were created by inserting the pat gene using ZFNs (see above). Similarly, Kumar et al. (2015) have used ZFNs to heritably knock in the pat gene in maize. We found two studies that have focused on gene stacking. D'Halluin et al. (2013) used $\mathrm{MNs}$ to add two transgenes, epsps and $h p p d$, which confer tolerance to glyphosate and 4-hydroxyphenylpyruvate dioxygenase inhibitor herbicides, respectively, to an already existing transgenic cotton (event GHB119; Lepidoptera resistance and glufosinate tolerance due to the cry2Ae gene and the bar gene, respectively). The whole stack of the four transgenes was inherited in the subsequent generations as a single genetic unit and field experiments confirmed that all of the genes were expressed. Ainley et al. (2013) introduced pat and aad1 genes that confer resistance to glufosinate and aryloxyphenoxypropionate herbicides, respectively, in maize. The gene knock-in was performed in two steps using ZFNs. Both of the traits were heritable and field experiments confirmed resistance to both of the herbicides.

\section{Site-directed nucleases for improvement of economically important animals}

The SDNs are also being developed in animals. There is a vast number of studies using model organisms or cell models such as zebrafish (Hwang et al., 2013; Zu et al., 2013), mouse and rat (Tesson et al., 2011; Li et al., 2013a; Fan et al., 2014), Drosophila (Liu et al., 2012; Beumer et al., 2013; Gratz et al., 2013), or Caenorhabditis elegans (Cheng et al., 2013; Chiu et al., 2013; Cho et al., 2013). The studies involving economically important animals are summed up in Table 2. The studied traits can be 


\begin{tabular}{|c|c|c|c|c|c|}
\hline Technique & $\begin{array}{l}\text { Type of } \\
\text { transformation }\end{array}$ & Species & Target gene & Target trait & Reference \\
\hline \multirow[t]{20}{*}{ ZFNs } & Gene knock-out & goat & blg & beta-lactoglobulin content in milk & Xiong et al., 2013, Song et al., 2015 \\
\hline & & chicken & ova & - & Fan et al., 2011 \\
\hline & & & mstn & increased muscle growth & Luo et al., 2014 \\
\hline & & pig & transgene $(\mathrm{egfp})$ & - & Watanabe et al., 2010 \\
\hline & & & ggta1 & - & Hauschild et al., 2011 \\
\hline & & & transgene (egfp) & - & Whyte et al., 2011 \\
\hline & & & ggta1 & - & Bao et al., 2014 \\
\hline & & & ggta1 & - & Hauschild-Quintern et al., 2013 \\
\hline & & & cmah & - & Kwon et al., 2013 \\
\hline & & & ggta1 & - & Li et al., 2013c \\
\hline & & & rela & disease resistance & Lillico et al., 2013 \\
\hline & & & $i / 2 r g$ & - & Watanabe et al., 2013 \\
\hline & & & $g h r$ & - & Hisamatsu et al., 2015 \\
\hline & & & mstn & increased muscle growth & Huang et al., 2014a \\
\hline & & & mstn & increased muscle growth & Qian et al., 2015 \\
\hline & & sheep & mstn & increased muscle growth & Zhang et al., 2014a \\
\hline & & trout & $s d Y$ & - & Yano et al., 2014 \\
\hline & & yellow catfish & mstn & increased muscle growth & Dong et al., 2011 \\
\hline & Gene knock-in & cow & transgene $(h L Y Z)$ & disease resistance & Liu et al., 2014 \\
\hline & & pig & $c t f r$ & - & Klymiuk et al., 2014 \\
\hline \multirow[t]{13}{*}{ TALENs } & Gene knock-out & chicken & ova & - & Park et al., 2014 \\
\hline & & cow & acan11, gdf8, prnp & - & Carlson et al., 2012 \\
\hline & & & polled & dehornation & Tan et al., 2013 \\
\hline & & & bsa & - & Moghaddassi et al., 2014 \\
\hline & & & mstn & increased muscle growth & Proudfoot et al., 2015 \\
\hline & & & $b / g$ & beta-lactoglobulin content in milk & Wei et al., 2015 \\
\hline & & goat & blg & beta-lactoglobulin content in milk & Cui et al., 2015 \\
\hline & & pig & rela, $I d r l$ & disease resistance & Carlson et al., 2012 \\
\hline & & & rela & disease resistance & Lillico et al., 2013 \\
\hline & & & ggta1 & - & Xin et al., 2013 \\
\hline & & & rag & - & Huang et al., 2014a \\
\hline & Gene knock-in & cow & $\begin{array}{l}\text { transgene }(h E P O) \\
\text { cisgene }(p o l l e d)\end{array}$ & dehornation & $\begin{array}{l}\text { Lee et al., } 2014 \\
\text { Tan et al., } 2013\end{array}$ \\
\hline & & goat & transgene $(h L F)$ & human lactoferrin content in milk & Cui et al., 2015 \\
\hline \multirow[t]{3}{*}{ CRISPR/Cas9 } & Gene knock-out & chicken & pax7 & - & Véron et al., 2015 \\
\hline & & cow & transgene $(g f p)$ & - & Choi et al., 2015 \\
\hline & & goat & mstn, nup, prp, blg & $\begin{array}{l}\text { increased muscle growth, } \\
\text { beta-lactoglobulin content in milk }\end{array}$ & Ni et al., 2014 \\
\hline \multirow[t]{17}{*}{ CRISPR/Cas9 } & Gene knock-out & goat & mstn, fgf5 & increased muscle growth, hair length & Wang et al., 2015c \\
\hline & & pig & $v W F$ & - & Hai et al., 2014 \\
\hline & & & FoxN1 & - & Jae-Hoon et al., 2014 \\
\hline & & & ggta1, cmah, igb3s & - & Li et al., 2015 \\
\hline & & & cd163, cd1d & - & Whitworth et al., 2014 \\
\hline & & & tyr, park2, pink1 & - & Zhou et al., 2015 \\
\hline & & & npc1/1 & - & Wang et al., 2015e \\
\hline & & & ggta1, cmah & - & Estrada et al., 2015 \\
\hline & & & mitf & - & Wang et al., 2015d \\
\hline & & & $m s t n$ & increased muscle growth & Wang et al., $2015 a$ \\
\hline & & & bmp15 & - & He et al., 2015 \\
\hline & & salmon & tyr, slc45a2 & - & Edvardsen et al., 2014 \\
\hline & & sheep & mstn & increased muscle growth & Han et al., 2014, Crispo et al., 2015 \\
\hline & & tilapia & $\begin{array}{l}\text { nanos2, nanos3, } d m \\
r t 1, \text { Fox } 2\end{array}$ & - & Li et al., 2014b \\
\hline & Gene knock-in & pig & transgene $(g f p)$ & 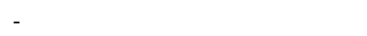 & Ruan et al., 2015 \\
\hline & & & transgene $(h A L B)$ & human albumin content in blood & Peng et al., 2015 \\
\hline & $\begin{array}{l}\text { Gene knock-out/ } \\
\text { knock-in }\end{array}$ & cow & nanog & - & Heo et al., 2014 \\
\hline
\end{tabular}

divided into three groups: (1) medical applications (xenotransplantation and disease model), (2) improvement of end-products, and (3) disease and pathogen resistance.
The domestic pig (Sus scrofa) is the most often studied animal species as it is economically important and has long been used as a biological model. Due to physiological and anatomical similarity to humans, the pig is used as a model for human diseases and as a source 
of organs for xenotransplantation (Bao et al., 2014; Petersen and Niemann, 2015a). Therefore, a majority of the genome modifications in pigs performed with SDNs are intended to create such disease models or to facilitate the use of the organs for xenotransplantations. For example, Yang et al. (2011) used ZFNs to create pigs with a ppar- $Y$ gene knock-out to study the role of this gene in cardiovascular diseases. A number of works studied the knock-out of the ggta1 gene using ZFNs, TALENs, or CRISPR/Cas; this gene encodes the $\alpha-1,3$-galactosyl-transferase generating the $\mathrm{Gal}$ epitopes that are responsible for immune rejection of organs in pig-to-human xenotransplantation (Hauschild et al., 2011; Hauschild-Quintern et al., 2013; Li et al., 2013c; Xin et al., 2013; Bao et al., 2014; Yao et al., 2014; Li et al., 2015). Even though those genome modifications are of limited agronomical significance, the knowledge and experience obtained in these studies can help to develop animals with agronomically beneficial traits.

Among the studies aimed at such traits, the most often studied is the myostatin ( $m s t n$ ) gene encoding the protein which is a negative regulator of muscle growth. The knock-out of the mstn gene thus results in a substantial increase of skeletal muscle mass and in increased meat production. Using SDNs, the gene was artificially mutated in cattle (Luo et al., 2014; Proudfoot et al., 2015) and pigs (Huang et al., 2014b; Qian et al., 2015; Wang et al., 2015b), but also in smaller livestock species like sheep (Han et al., 2014; Zhang et al., 2014a; Crispo et al., 2015; Proudfoot et al., 2015) and goat (Ni et al., 2014; Wang et al., 2015c). In most cases, the studies have chosen to target the first exon of the gene and obtained small deletions and insertions in the gene. In the studies of Proudfoot et al. (2015), Han et al. (2014), Luo et al. (2014), Crispo et al. (2015), Wang et al. (2015c), and Wang et al. (2015a) several offspring were born that had the desired mstn knock-out. The animals were visually different from the wild type individuals with an obvious difference in muscle mass and a difference was also observed during histological comparison of the muscles (Luo et al., 2014; Qian et al., 2015). Qian et al. (2015) have also found changes in the structure of the skeleton and fat content in the meat. Apart from livestock species, SDNs were also used in fish. Using ZFNs, Dong et al. (2011) successfully mutated the mstn gene in yellow catfish
(Pelteobagrus fulvidraco), an important freshwater aquaculture species.

The nutritional value of milk was the subject of four studies that focused on the blg gene responsible for levels of beta-lactoglobulin in milk. Beta-lactoglobulin is a major milk protein and a dominant allergen. In the study by $\mathrm{Yu}$ et al. (2011), the gene was knocked out in cattle using ZFNs. The majority of the mutations were small deletions and insertions, some of them bi-allelic. One viable calf was obtained that bore the desired bi-allelic mutation. The blg gene knockout has also been attempted in goats: Xiong et al. (2013) and Song et al. (2015) using ZFNs; Ni et al. (2014) using CRISPR/Cas, and Cui et al. (2015) using TALENs. In the study by Cui et al. (2015), ten viable goat kids were obtained that bore the desired mono-allelic mutation; all of the animals grew to adulthood. Subsequently, the second blg allele was targeted in those animals by knocking in the $\mathrm{h} L f$ gene encoding human lactoferrin; a glycoprotein involved in iron adsorption and in non-specific immune-system response in the intestinal tract. After inducing the lactation, the analysis of the milk showed that mono-allelic mutants had a reduced level of beta-lactoglobulin while the milk of the bi-allelic mutants was completely beta-lactoglobulin free. Moreover, the milk of the $h L f$ mutants contained the lactoferrin.

Disease resistance is also an important trait as diseases are responsible for decreased yield and require the use of medicaments that are often costly and may also decrease the quality of end-products. Two studies have focused on the rela (v-rel reticuloendotheliosis viral oncogene homolog A) gene in pigs which has been proposed to play a role in resistance against African swine fever [Carlson et al. (2012) using TALENs, Lillico et al. (2013) using ZFN and TALENs]. Carlson et al. (2012) successfully produced embryos only (with several small deletions from their genomes), whilst Lillico et al. (2013) managed to obtain several viable piglets carrying the desirable mutations by both ZFNs and TALENs.

An interesting application of the SDNs is described in the study by Tan et al. (2013) who focused on presence of horns in cattle. Horns are often removed in cattle in order to improve the safety of both the animals and farm employees. Horn removal is, however, painful 
and stressful for the animals. Several cow breeds are naturally horn-free due to a dominant trait referred to as polled (i.e. lacking horns) with two allelic variants on chromosome 1; it would be possible to transfer the trait by traditional breeding but this would influence other important traits, such as milk production. Tan et al. (2013) have successfully knocked in the polled gene using TALENs in fibroblasts of horned cattle.

Several studies have created transgenic animals or investigated model transgenes, for example Watanabe et al. (2010) and Whyte et al. (2011) have used ZFNs to knock-out the fluorescent egfp (enhanced green fluorescent protein) gene in pigs. In the already mentioned study by Cui et al. (2015), the human lactoferrin gene was knocked in using TALENs. Liu et al. (2014) and Lee et al. (2014) have knocked in the human erythropoietin ( $h E p o$ ) gene in the $\beta$-casein gene locus in cattle using TALENs. The $\beta$-casein gene locus was also targeted in the study by Liu et al. (2014) who focused on mastitis in cows. Mastitis is a bacterial infection of mammary gland in the udder and is among the most common and costly diseases in dairy cattle. Liu et al. (2014) used ZFNs to knock-in the human lysozyme gene ( $h L y z)$ so that the transgenic cows would produce the lysozyme in the milk and thus become resistant to the bacteria causing the disease. Five transgenic calves were produced whose mammary glands, after infusion by viable bacterial cultures, remained uninfected and no systemic response was observed even after blood analysis.

\section{Genome editing using SDNs: an outlook}

The past decades have posed a number of challenges to modern agriculture. The world population is increasing at an ever-accelerating rate and so are concerns about food security. It is estimated, that by 2050 world agriculture will need to feed a global population of nine billion (Liu et al., 2013; Fichtner et al., 2014; Smyth et al., 2014). Moreover, the ongoing climate change is impacting weather conditions, water sources, and occurrence of pests and diseases (Bruce et al., 2013; Fichtner et al., 2014). Modern agriculture will need to face those challenges as well as contribute to the reduction of greenhouse gas emissions. The so-called sustainable intensification of agricultural production is necessary including better agricultural practices, soil and water management, and species improvement (Bruce et al., 2013; Rinaldo and
Ayliffe, 2015). It has been suggested that GMOs could contribute to achieve this (Bruce et al., 2013; Liu et al., 2013; Fichtner et al., 2014; Andersen et al., 2015).

The application of transgenic techniques brought an important improvement in the breeding process. Compared to the traditional techniques of conventional crossbreeding and induced mutagenesis, the transgenic techniques have permitted the realisation of specific desirable traits that often would not be available in the natural gene pool of the individual species (Privalle et al., 2012). Transgenesis was also expected to speed up the breeding process and enable release of new varieties with novel beneficial traits but instead, the approval of GMOs is time- and finance-consuming due to legal obligations (Fichtner et al., 2014; Araki and Ishii, 2015). The obtained GMOs need to be tested not only as conventional products but in addition field trials and feeding studies are required to obtain data for risk/safety assessment (Domingo and Giné Bordonaba, 2011). The random nature of transgene integration into the genome may lead to various frame shifts or inactivation of native genes and thus introduce more uncertainty in the risk assessment. Various procedures and guidelines on evaluating GMOs have been developed by international organizations such as Food and Agriculture Organization of the United Nations (ftp://ftp.fao.org/es/esn/food/allergygm.pdf), Organisation for Economic Co-Operation and Development (http://www.oecd.org/env/ehs/ biotrack/), Codex alimentarius (http:// www.bibliotecapleyades.net/ciencia/ ciencia_geneticfood121.htm) or by individual countries (USA, EU, etc.). The regulatory framework thus differs in various parts of the world and although it should be solely based on relevant scientific studies it may also reflect the attitude of the general public in individual countries (Bruce et al., 2013). The public has not fully accepted the concept of transgenic organisms and their associated food products, which has caused certain countries (such as many in the EU) to take a rather reserved view and to regulate the production and import of transgenic crops and animals, and derived products. Therefore, transgenic approaches have been limited and probably have not so far been used to their full potential (Finkelstein, 2016). 
The SDNs could offer a much more acceptable alternative to genetic modification. It is now possible to perform direct changes to the genome with an unprecedented precision and scale which can produce the desired trait without the necessity to introduce exogenous DNA (Belhaj et al., 2013; Lusser and Davies, 2013; Araki and Ishii, 2015). The approaches using SDNs are also much easier and straightforward and, in some cases, much less expensive than the traditional and/or transgenic techniques, for example CRISPR/Cas9 system can cost as little as $\$ 30$ per genome change (Ledford, 2015). The laboratories using SDN techniques do not need expensive equipment and the lab workers do not need years of training to use the techniques. Therefore, many laboratories around the world are able to adopt the techniques and successfully produce organisms carrying desired mutations (Carlson et al., 2013; Petersen and Niemann, 2015a). As a result, the research activity concerning the SDNs is developing quickly and many studies have been published recently, particularly on work using model organisms. Apart from model plant and animal species, studies have been carried out with economically important organisms and promising results have been obtained. However, a majority of the studies have achieved the mutation only at the cellular level and only a few went on to produce a full-grown organism; especially in the case of animals where the process is more complicated and time-consuming (Shukla et al., 2009; Yu et al., 2011; Li et al., 2012; Lillico et al., 2013; Han et al., 2014; Haun et al., 2014; Liu et al., 2014; Luo et al., 2014; Wang et al., 2014; Clasen et al., 2015; Proudfoot et al., 2015). The full-grown animals have been reported to live up to several months of age, but it is not clear yet whether they will maintain normal physiological function through to the adulthood (i.e. milk production or reproduction); the heritability of the traits or the occurrence of off-target effects were also not verified in all of the studies. Probably the most advanced studies are those involving plants, e.g. Li et al. (2012), Shukla et al. (2009), Haun et al. (2014), Wang et al. (2014) and Clasen et al. (2015) that have produced morphologically normal phenotypes with the traits being faithfully transmitted to the next generations. Moreover, the ZFN technique used in Shukla et al. (2009) is commercially available as the EXZACT Precision Technology developed and licensed by Dow AgroSciences (http:// www.exzactprecisiontechnology.com). There have been several patent applications, e.g. Li et al. (2012), Haun et al. (2014), Clasen et al. (2015), however, none of the above mentioned studies have led to commercialization yet.

The market release of plants or animals designed using SDNs is, above all, complicated by the currently uncertain legal and regulatory status, especially in the EU when it is not clear whether these new techniques will fall under the GMO regulations (Araki and Ishii, 2015; Rinaldo and Ayliffe, 2015). In the Cartagena Protocol on Biosafety, the GMOs (or "living modified organisms") are defined as "any living organism that possesses a novel combination of genetic material obtained through the use of modern biotechnology" (https://www.cbd.int/doc/legal/ cartagena-protocol-en.pdf). Similarly in the EU, the GMOs are defined as organisms "in which the genetic material has been altered in a way that does not occur naturally by mating and/or natural recombination" (http://eur-lex.europa.eu/ legal-content/EN/TXT/ ? uri=CELEX: 32001L0018). Therefore, the criterion to consider the SDN-developed organisms as transgenic would be the incorporation of exogenic DNA in the target genome (Hartung and Schiemann, 2014; Araki and Ishii, 2015). This is only the case of SDN-3 but not SDN-1 and certain types of SDN-2 (Lusser and Davies, 2013; Hartung and Schiemann, 2014). Even though foreign DNA can be unintentionally incorporated, the unwanted sequences may be removed by backcrossing or segregation to obtain recombinant DNA-free organisms (Lusser and Davies, 2013; Hartung and Schiemann, 2014; Rinaldo and Ayliffe, 2015). Moreover, SDNs do not allow, especially in case of small indels, differentiation from individuals obtained by natural or induced mutagenesis which is, however, not considered under the GMO regulations; this also implies that identification of SDN-derived organisms would not be possible (Curtin et al., 2012; Lusser and Davies, 2013; Araki et al., 2014; Hartung and Schiemann, 2014; Rinaldo and Ayliffe, 2015). However, the SDNs possess some risks that need to be addressed. The SDNs can target unwanted DNA sequences thus causing the already mentioned off-target effects that can cause silent or loss-of-function mutations, or cause immunogenicity or toxicity by changing the structure of proteins (Hartung and Schiemann, 2014; Araki and Ishii, 2015). The DNA methylation might also be modified which could affect gene expression (Ribarits et al., 
2014). However, with the increased precision of the SDN techniques, unwanted mutations should occur much less often compared to transgenesis or induced mutagenesis (Carlson et al., 2013; Ribarits et al., 2014; Rinaldo and Ayliffe, 2015). The occurrence of off-target effects can further be reduced by improving binding specificity, use of software tools or by in vitro selection of the most appropriate SDN (Hartung and Schiemann, 2014; Naito et al., 2014; Xie et al., 2014). With the advances in whole-genome sequencing, detection of the organisms carrying unwanted genome changes is also becoming more straightforward (Carlson et al., 2013; Araki and Ishii, 2015). The targeted gene also remains in its normal chromosomal context which also reduces possible effects on gene expression (Ribarits et al., 2014). Some commentators therefore assert that these organisms, and derived products, may be exempted from the GMO regulations (Hartung and Schiemann, 2014; Ribarits et al., 2014; Araki and Ishii, 2015; Rinaldo and Ayliffe, 2015).

It is therefore necessary to establish the legal status of the SDNs. However, only a handful of national regulators have yet tried to address the issue; so far, some discussion has taken place in the USA, the EU, Australia, New Zealand, and Argentina but no final decision has been made (Smyth et al., 2014; Araki and Ishii, 2015). The experts have focused mainly on the ZFNs and also on TALENs while the CRISPR/Cas9 system has not yet been discussed; in general, the conclusions were that the ZFN technology would not fall under the GMO regulations if no exogenous DNA was incorporated in the target genome, i.e. SDN-1 and under certain conditions SDN-2 (Hartung and Schiemann, 2014; Ribarits et al., 2014). The European Food Safety Authority (EFSA) has issued an opinion regarding plants developed by SDN-3 stating that the SDN-3 techniques do not differ from other GM techniques but hazards associated with the gene introduction via SDN-3 can be reduced compared to other $\mathrm{GM}$ techniques. The plants should be evaluated on a case by case basis and lesser amounts of data may be needed for the risk assessment of such plants. The SDN-1 and SDN-2 techniques were, however, not discussed (EFSA, 2012). The New Zealand Environmental Protection Authority has declared that SDN-1 are not transgenic techniques under the local GMO act but this interpretation has been challenged by the New
Zealand Sustainability Council with the aim of over-turning the decision (Araki and Ishii, 2015). In the USA, the Animal and Plant Health Inspection Service of the United States Department of Agriculture have responded to inquiries by Dow AgroSciences (http:// www.aphis.usda.gov/biotechnology/downloads/ reg_loi/APHIS_response_DOW_ZFN_IPK1 030812.pdf) and Cellestis Plant Sciences (http:// www.aphis.usda.gov/biotechnology/downloads/ reg_loi/15-071-01air_resp.pdf; http:// www.aphis.usda.gov/biotechnology/downloads/ reg_loi/aphis_response_cellectis_potato.pdf) stating that the companies' plant varieties developed using ZFNs (Shukla et al., 2009) and TALENs (Haun et al., 2014; Clasen et al., 2015) would not be regulated under the local GMO legislation; however, other national agencies that also have a say in the matter (US Environmental Protection Agency, US Food and Drug Administration) have not expressed their opinions yet.

The issue is thus not clear yet, however, a decision should be taken soon for the benefit of both the producers and the consumers (Curtin et al., 2012; Belhaj et al., 2013; Ribarits et al., 2014; Araki and Ishii, 2015; Rinaldo and Ayliffe, 2015). The regulatory systems not only ensure the safety and efficacy of the products introduced to the market but have also economic ramifications and influence the technological innovation process especially in the case of biotechnologies (Bruce et al., 2013; Smyth et al., 2014). The form of the regulation affects the commercial and technological strategies of the companies, the type of the companies that would get involved and be successful in development of a transgenic organism, and also the ability of the sector to readily respond to the current trends and market situation (Bruce et al., 2013; Hartung and Schiemann, 2014; Smyth et al., 2014). In the case of GMOs, if the regulation and approval process of a new product is too complicated, lengthy or vague, the companies will not be motivated into its development and later commercialization. A prime example of this is the Enviropig ${ }^{\mathrm{TM}}$, a genetically modified pig with a more efficient phosphorus metabolism. The pig originally was developed in late 1990s, however, the subsequent approval process took well over a decade by which time the company decided to withdraw the application. One of the reasons for this withdrawal was that other technological advances offered a less elegant, albeit more 
practical, solution to the problem (Bruce et al., 2013). Similarly, Dow AgroSciences has apparently already dropped the ZFN-based maize project (Ledford, 2013). The companies thus need to be sure that the substantial costs invested in the development would not be lost if the product could not be approved or would be out-dated by the time the market release would be possible. Some argue that the lower costs of development of a new organism using the SDNs might outweigh the increased costs of the approval process if the SDNs were regulated under the existing GMO legislation (Lusser and Davies, 2013). However, if the use of SDNs was not be regulated in this way it seems very likely that this would promote research and development (Curtin et al., 2012; Bruce et al., 2013; Hartung and Schiemann, 2014). With the feasibility of the techniques, possible less controversial status in the eye of the general population and lower costs of both the research and approval phase, even smaller companies that do not usually have the financial means to develop a GMO could be motivated to participate in the research (Curtin et al., 2012; Bruce et al., 2013). It is our conclusion that the status of SDNs needs to be clarified as soon as possible if the new techniques reviewed above are to be used to their full potential and any possible benefits to society, the environment and human health realised.

\section{Acknowledgements}

This work was funded by the Ministry of Agriculture of the Czech Republic (Grant No. MZe RO0414 ) and by the National Agency for Agricultural Research (Grant No. QI101B267).

\section{References}

Ainley, W.M., Sastry-Dent, L., Welter, M.E., Murray, M.G., Zeitler, B., Amora, R., Corbin, D.R., Miles, R.R., Arnold, N.L., Strange, T.L., et al. (2013). Trait stacking via targeted genome editing. Plant Biotechnol. J. 11, 1126-1134.

Andersen, M.M., Landes, X., Xiang, W., Anyshchenko, A., Falhof, J., Østerberg, J.T., Olsen, L.I., Edenbrandt, A.K., Vedel, S.E., Thorsen, B.J., et al. (2015). Feasibility of new breeding techniques for organic farming. Trends Plant Sci. 20, 426-434.

Antunes, M.S., Smith, J.J., Jantz, D., and Medford, J.I. (2012). Targeted DNA excision in Arabidopsis by a re-engineered homing endonuclease. BMC Biotechnol. 12, 86.
Araki, M., and Ishii, T. (2015). Towards social acceptance of plant breeding by genome editing. Trends Plant Sci. 20, 145-149.

Araki, M., Nojima, K., and Ishii, T. (2014). Caution required for handling genome editing technology. Trends Biotechnol. 32, 234-237.

Bao, L., Chen, H., Jong, U., Rim, C., Li, W., Lin, X., Zhang, D., Luo, Q., Cui, C., Huang, H., et al. (2014). Generation of GGTA1 biallelic knockout pigs via zinc-finger nucleases and somatic cell nuclear transfer. Sci. China Life Sci. 57, 263-268.

Belhaj, K., Chaparro-Garcia, A., Kamoun, S., and Nekrasov, V. (2013). Plant genome editing made easy: targeted mutagenesis in model and crop plants using the CRISPR/Cas system. Plant Methods 9, 39.

Belhaj, K., Chaparro-Garcia, A., Kamoun, S., Patron, N.J., and Nekrasov, V. (2015). Editing plant genomes with CRISPR/Cas9. Curr. Opin. Biotechnol. 32, 76-84.

Beumer, K.J., Trautman, J.K., Christian, M., Dahlem, T.J., Lake, C.M., Hawley, R.S., Grunwald, D.J., Voytas, D.F., and Carroll, D. (2013). Comparing Zinc Finger Nucleases and Transcription Activator-Like Effector Nucleases for Gene Targeting in Drosophila. G3 (Bethesda) 3, 1717-1725.

Beyer, P., Al-Babili, S., Ye, X., Lucca, P., Schaub, P., Welsch, R., and Potrykus, I. (2002). Golden Rice: Introducing the $\beta$-Carotene Biosynthesis Pathway into Rice Endosperm by Genetic Engineering to Defeat Vitamin A Deficiency. J. Nutr. 132, 506S-510S.

Boettcher, M., and McManus, Michael T. (2015). Choosing the Right Tool for the Job: RNAi, TALEN, or CRISPR. Mol. Cell 58, 575-585.

Bonas, U., Stall, R.E., and Staskawicz, B. (1989). Genetic and structural characterization of the avirulence gene avrBs 3 from Xanthomonas campestris pv. vesicatoria. Mol. Gen. Genet. 218, 127-136.

Bortesi, L., and Fischer, R. (2015). The CRISPR/ Cas9 system for plant genome editing and beyond. Biotechnology Advances 33, 41-52.

Brooks, C., Nekrasov, V., Lippman, Z.B., and Van Eck, J. (2014). Efficient Gene Editing in Tomato in the First Generation Using the Clustered Regularly Interspaced Short Palindromic Repeats/CRISPR-Associated9 System. Plant Physiol. 166, 1292-1297.

Bruce, A., Castle, D., Gibbs, C., Tait, J., and Whitelaw, C.B. (2013). Novel GM animal technologies and their governance. Transgenic Res. 22, 681-695. 
Budhagatapalli, N., Rutten, T., Gurushidze, M., Kumlehn, J., and Hensel, G. (2015). Targeted Modification of Gene Function Exploiting Homology-Directed Repair of TALEN-Mediated Double-Strand Breaks in Barley. G3 (Bethesda) 5, 1857-1863.

Cai, Y., Chen, L., Liu, X., Sun, S., Wu, C., Jiang, B., Han, T., and Hou, W. (2015). CRISPR/ Cas9-Mediated Genome Editing in Soybean Hairy Roots. PLoS ONE 10, e0136064.

Cantos, C., Fransisco, P., Trijatmiko, K.R., Slamet-Loedin, I., and Chadha-Mohanty, P.K. (2014). Identification of 'safe harbor' loci in indica rice genome by harnessing the property of zinc-finger nucleases to induce DNA damage and repair. Front. Plant Sci. 5.

Cao, A., Xing, L., Wang, X., Yang, X., Wang, W., Sun, Y., Qian, C., Ni, J., Chen, Y., Liu, D., et al. (2011). Serine/threonine kinase gene Stpk-V, a key member of powdery mildew resistance gene Pm21, confers powdery mildew resistance in wheat. Proc. Nat. Acad. Sci. USA 108, 7727-7732.

Carlson, D.F., Tan, W., Hackett, P.B., and Fahrenkrug, S.C. (2013). Editing livestock genomes with site-specific nucleases. Reprod. Fertil. Dev. 26, 74-82.

Carlson, D.F., Tan, W., Lillico, S.G., Stverakova, D., Proudfoot, C., Christian, M., Voytas, D.F., Long, C.R., Whitelaw, C.B.A., and Fahrenkrug, S.C. (2012). Efficient TALEN-mediated gene knockout in livestock. Proc. Nat. Acad. Sci. USA 109, 17382-17387.

Cermak, T., Doyle, E.L., Christian, M., Wang, L., Zhang, Y., Schmidt, C., Baller, J.A., Somia, N.V., Bogdanove, A.J., and Voytas, D.F. (2011). Efficient design and assembly of custom TALEN and other TAL effector-based constructs for DNA targeting. Nucleic Acids Res. 39, e82.

Char, S.N., Unger-Wallace, E., Frame, B., Briggs, S.A., Main, M., Spalding, M.H., Vollbrecht, E., Wang, K., and Yang, B. (2015). Heritable site-specific mutagenesis using TALENs in maize. Plant Biotechnol. J. 13, 1002-1010.

Chen, K., and Gao, C. (2013). TALENs: Customizable Molecular DNA Scissors for Genome Engineering of Plants. J. Genet. Genomics 40, 271-279.

Cheng, Z., Yi, P., Wang, X., Chai, Y., Feng, G., Yang, Y., Liang, X., Zhu, Z., Li, W., and Ou, G. (2013). Conditional targeted genome editing using somatically expressed TALENs in $C$. elegans. Nat. Biotechnol. 31, 934-937.
Chiu, H., Schwartz, H.T., Antoshechkin, I., and Sternberg, P.W. (2013). Transgene-Free Genome Editing in Caenorhabditis elegans Using CRISPR-Cas. Genetics 195, 1167-1171.

Cho, S.W., Lee, J., Carroll, D., Kim, J.-S., and Lee, J. (2013). Heritable Gene Knockout in Caenorhabditis elegans by Direct Injection of Cas9-sgRNA Ribonucleoproteins. Genetics 195, 1177-1180.

Choi, W., Yum, S., Lee, S., Lee, W., Lee, J., Kim, S., Koo, O., Lee, B., and Jang, G. (2015). Disruption of exogenous eGFP gene using RNA-guided endonuclease in bovine transgenic somatic cells. Zygote 23, 916-923.

Clasen, B.M., Stoddard, T.J., Luo, S., Demorest, Z.L., Li, J., Cedrone, F., Tibebu, R., Davison, S., Ray, E.E., Daulhac, A., et al. (2015). Improving cold storage and processing traits in potato through targeted gene knockout. Plant Biotechnol. J. in press.

Crispo, M., Mulet, A.P., Tesson, L., Barrera, N., Cuadro, F., dos Santos-Neto, P.C., Nguyen, T.H., Crénéguy, A., Brusselle, L., Anegón, I., et al. (2015). Efficient Generation of Myostatin Knock-Out Sheep Using CRISPR/Cas9 Technology and Microinjection into Zygotes. PLoS ONE 10, e0136690.

Cui, C., Song, Y., Liu, J., Ge, H., Li, Q., Huang, $H_{\text {., }} \mathrm{Hu}$, L., Zhu, H., Jin, Y., and Zhang, Y. (2015). Gene targeting by TALEN-induced homologous recombination in goats directs production of $\beta$-lactoglobulin-free, high-human lactoferrin milk. Sci. Rep. 5.

Curtin, S.J., Voytas, D.F., and Stupar, R.M. (2012). Genome Engineering of Crops with Designer Nucleases. Plant Genome 5, 42-50.

Curtin, S.J., Zhang, F., Sander, J.D., Haun, W.J., Starker, C., Baltes, N.J., Reyon, D., Dahlborg, E.J., Goodwin, M.J., Coffman, A.P., et al. (2011). Targeted Mutagenesis of Duplicated Genes in Soybean with Zinc-Finger Nucleases. Plant Physiol. 156, 466-473.

Čermák, T., Baltes, N., Čegan, R., Zhang, Y., and Voytas, D. (2015). High-frequency, precise modification of the tomato genome. Genome Biol. 16, 1-15.

D'Halluin, K., Vanderstraeten, C., Van Hulle, J., Rosolowska, J., Van Den Brande, I., Pennewaert, A., D'Hont, K., Bossut, M., Jantz, D., Ruiter, R., et al. (2013). Targeted molecular trait stacking in cotton through targeted double-strand break induction. Plant Biotechnol. J. 11, 933-941.

de Pater, S., Pinas, J.E., Hooykaas, P.J.J., and van der Zaal, B.J. (2013). ZFN-mediated gene 
targeting of the Arabidopsis protoporphyrinogen oxidase gene through Agrobacterium-mediated floral dip transformation. Plant Biotechnol. J. 11, 510-515.

De Wilde, T., De Meulenaer, B., Mestdagh, F., Govaert, Y., Vandeburie, S., Ooghe, W., Fraselle, S., Demeulemeester, K., Van Peteghem, C., Calus, A., et al. (2005). Influence of Storage Practices on Acrylamide Formation during Potato Frying. J. Agric. Food Chem. 53, 6550-6557.

Djukanovic, V., Smith, J., Lowe, K., Yang, M., Gao, H., Jones, S., Nicholson, M.G., West, A., Lape, J., Bidney, D., et al. (2013). Male-sterile maize plants produced by targeted mutagenesis of the cytochrome P450-like gene (MS26) using a re-designed I-Crel homing endonuclease. Plant J. 76, 888-899.

Domingo, J.L., and Giné Bordonaba, J. (2011). A literature review on the safety assessment of genetically modified plants. Environ. Int. 37, 734-742.

Dong, Z., Ge, J., Li, K., Xu, Z., Liang, D., Li, J., Li, J., Jia, W., Li, Y., Dong, X., et al. (2011). Heritable Targeted Inactivation of Myostatin Gene in Yellow Catfish (Pelteobagrus fulvidraco) Using Engineered Zinc Finger Nucleases. PLoS ONE 6, e28897.

Dossa, S.G., Sparks, A., Vera Cruz, C., and Oliva, R. (2015). Decision tools for bacterial blight resistance gene deployment in ricebased agricultural ecosystems. Front. Plant Sci. 6.

Du, H., Zeng, X., Zhao, M., Cui, X., Wang, Q., Yang, H., Cheng, H., and Yu, D. (2016). Efficient targeted mutagenesis in soybean by TALENs and CRISPR/Cas9. J. Biotechnol. 217, 90-97.

Edvardsen, R.B., Leininger, S., Kleppe, L., Skaftnesmo, K.O., and Wargelius, A. (2014). Targeted Mutagenesis in Atlantic Salmon (Salmo salar L.) Using the CRISPR/Cas9 System Induces Complete Knockout Individuals in the F0 Generation. PLoS ONE 9, e108622.

EFSA (2012). Scientific opinion addressing the safety assessment of plants developed using Zinc Finger Nuclease 3 and other SiteDirected Nucleases with similar function. EFSA J. 10, 2943-2974.

Estrada, J.L., Martens, G., Li, P., Adams, A., Newell, K.A., Ford, M.L., Butler, J.R., Sidner, R., Tector, M., and Tector, J. (2015). Evaluation of human and non-human primate antibody binding to pig cells lacking GGTA1/CMAH/ B4GalNT2 genes. Xenotransplantation 22, 194-202.

Fan, B., Huang, P., Zheng, S., Sun, Y., Fang, C., and Sun, Z. (2011). Assembly and in vitro Functional Analysis of Zinc Finger Nuclease Specific to the 3' Untranslated Region of Chicken Ovalbumin Gene. Anim. Biotechnol. 22, 211-222.

Fan, D., Liu, T., Li, C., Jiao, B., Li, S., Hou, Y., and Luo, K. (2015). Efficient CRISPR/Cas9mediated Targeted Mutagenesis in Populus in the First Generation. Sci. Rep. 5, 12217.

Fan, F., Geurts, A.M., Pabbidi, M.R., Smith, S.V., Harder, D.R., Jacob, H., and Roman, R.J. (2014). Zinc-Finger Nuclease Knockout of Dual-Specificity Protein Phosphatase-5 Enhances the Myogenic Response and Autoregulation of Cerebral Blood Flow in $\mathrm{FHH}$. $1^{\mathrm{BN}}$ Rats. PLoS ONE 9, e112878.

Feng, Z., Zhang, B., Ding, W., Liu, X., Yang, D.L., Wei, P., Cao, F., Zhu, S., Zhang, F., Mao, Y., et al. (2013). Efficient genome editing in plants using a CRISPR/Cas system. Cell Res. 23, 1229-1232.

Fichtner, F., Urrea Castellanos, R., and Ülker, B. (2014). Precision genetic modifications: a new era in molecular biology and crop improvement. Planta 239, 921-939.

Finkelstein, P.E. (2016). Genetically Modified Foods: A Brief Overview of the Risk Assessment Process. GM Crops Food, in press.

Fitch, M.M.M., Manshardt, R.M., Gonsalves, D., Slightom, J.L., and Sanford, J.C. (1992). Virus Resistant Papaya Plants Derived from Tissues Bombarded with the Coat Protein Gene of Papaya Ringspot Virus. Nat. Biotechnol. 10, 1466-1472.

Flores, T., Karpova, O., Su, X., Zeng, P., Bilyeu, K., Sleper, D., Nguyen, H., and Zhang, Z. (2008). Silencing of GmFAD3 gene by siRNA leads to low a-linolenic acids (18:3) of fad3mutant phenotype in soybean [Glycine max (Merr.)]. Transgenic Res. 17, 839-850.

Gao, H., Smith, J., Yang, M., Jones, S., Djukanovic, V., Nicholson, M.G., West, A., Bidney, D., Falco, S.C., Jantz, D., et al. (2010). Heritable targeted mutagenesis in maize using a designed endonuclease. Plant J. 61, 176-187.

Gao, J., Wang, G., Ma, S., Xie, X., Wu, X., Zhang, X., Wu, Y., Zhao, P., and Xia, Q. (2015). CRISPR/Cas9-mediated targeted 
mutagenesis in Nicotiana tabacum. Plant Mol. Biol. 87, 99-110.

Gratz, S.J., Cummings, A.M., Nguyen, J.N., Hamm, D.C., Donohue, L.K., Harrison, M.M., Wildonger, J., and O'Connor-Giles, K.M. (2013). Genome Engineering of Drosophila with the CRISPR RNA-Guided Cas9 Nuclease. Genetics 194, 1029-1035.

Gupta, M., DeKelver, R.C., Palta, A., Clifford, C., Gopalan, S., Miller, J.C., Novak, S., Desloover, D., Gachotte, D., Connell, J., et al. (2012). Transcriptional activation of Brassica napus $\beta$ ketoacyl-ACP synthase II with an engineered zinc finger protein transcription factor. Plant Biotechnol. J. 10, 783-791.

Gurushidze, M., Hensel, G., Hiekel, S., Schedel, S., Valkov, V., and Kumlehn, J. (2014). TrueBreeding Targeted Gene Knock-Out in Barley Using Designer TALE-Nuclease in Haploid Cells. PLoS ONE 9, e92046.

Hai, T., Teng, F., Guo, R., Li, W., and Zhou, Q. (2014). One-step generation of knockout pigs by zygote injection of CRISPR/Cas system. Cell Res. 24, 372-375.

Han, H., Ma, Y., Wang, T., Lian, L., Tian, X., Hu, R., Deng, S., Li, K., Wang, F., Li, N., et al. (2014). One-step generation of myostatin gene knockout sheep via the CRISPR/Cas9 system. Front. Agric. Sci. Eng. 1, 2-5.

Harrison, M.M., Jenkins, B.V., O'Connor-Giles, K.M., and Wildonger, J. (2014). A CRISPR view of development. Genes Dev. 28, 1859-1872.

Hartung, F., and Schiemann, J. (2014). Precise plant breeding using new genome editing techniques: opportunities, safety and regulation in the EU. Plant J. 78, 742-752.

Haun, W., Coffman, A., Clasen, B.M., Demorest, Z.L., Lowy, A., Ray, E., Retterath, A., Stoddard, T., Juillerat, A., Cedrone, F., et al. (2014). Improved soybean oil quality by targeted mutagenesis of the fatty acid desaturase 2 gene family. Plant Biotechnol. J. 12, 934-940.

Hauschild-Quintern, J., Petersen, B., Queisser, A.-L., Lucas-Hahn, A., Schwinzer, R., and Niemann, H. (2013). Gender non-specific efficacy of ZFN mediated gene targeting in pigs. Transgenic Res. 22, 1-3.

Hauschild, J., Petersen, B., Santiago, Y., Queisser, A.-L., Carnwath, J.W., Lucas-Hahn, A., Zhang, L., Meng, X., Gregory, P.D., Schwinzer, R., et al. (2011). Efficient generation of a biallelic knockout in pigs using zinc-finger nucleases. Proc. Nat. Acad. Sci. USA 108, 12013-12017.
He, C., Gouble, A., Bourdel, A., Manchev, V., Poirot, L., Paques, F., Duchateau, P., Edelman, A., and Danos, O. (2014). Lentiviral protein delivery of meganucleases in human cells mediates gene targeting and alleviates toxicity. Gene Ther. 21, 759-766.

He, Z., Shi, X., Du, B., Qin, Y., Cong, P., and Chen, Y. (2015). Highly efficient enrichment of porcine cells with deletions induced by CRISPR/Cas9 using dual fluorescence selection. J. Biotechnol. 214, 69-74.

Heo, Y.T., Quan, X., Xu, Y.N., Baek, S., Choi, H., Kim, N.-H., and Kim, J. (2014). CRISPR/Cas9 Nuclease-Mediated Gene Knock-In in BovineInduced Pluripotent Cells. Stem Cells Dev. 24, 393-402.

Hisamatsu, S., Sakaue, M., Takizawa, A., Kato, T., Kamoshita, M., Ito, J., and Kashiwazaki, N. (2015). Knockout of targeted gene in porcine somatic cells using zinc-finger nuclease. Anim. Sci. J. 86, 132-137.

Huang, J., Guo, X., Fan, N., Song, J., Zhao, B., Ouyang, Z., Liu, Z., Zhao, Y., Yan, Q., Yi, X., et al. (2014a). RAG1/2 Knockout Pigs with Severe Combined Immunodeficiency. J. Immunol. 193, 1496-1503.

Huang, X.-J., Zhang, H.-X., Wang, H., Xiong, K., Qin, L., and Liu, H. (2014b). Disruption of the Myostatin Gene in Porcine Primary Fibroblasts and Embryos Using Zinc-Finger Nucleases. Mol. Cells 37, 302-306.

Hwang, W.Y., Fu, Y., Reyon, D., Maeder, M.L., Tsai, S.Q., Sander, J.D., Peterson, R.T., Yeh, J.R.J., and Joung, J.K. (2013). Efficient genome editing in zebrafish using a CRISPRCas system. Nat. Biotechnol. 31, 227-229.

Ishino, Y., Shinagawa, H., Makino, K., Amemura, M., and Nakata, A. (1987). Nucleotide sequence of the iap gene, responsible for alkaline phosphatase isozyme conversion in Escherichia coli, and identification of the gene product. J. Bacteriol. 169, 5429-5433.

Ito, Y., Nishizawa-Yokoi, A., Endo, M., Mikami, M., and Toki, S. (2015). CRISPR/Cas9mediated mutagenesis of the RIN locus that regulates tomato fruit ripening. Biochem. Biophys. Res. Commun. 467, 76-82.

Jacobs, T.B., LaFayette, P.R., Schmitz, R.J., and Parrott, W.A. (2015). Targeted genome modifications in soybean with CRISPR/Cas9. BMC Biotechnol. 15, 16.

Jae-Hoon, Y., In-Sul, H., Jae Kyung, P., Dae-Jin, K., Seoki, I., Eung-Woo, P., Jeong-Woong, L., Choon-Keun, P., and Seongsoo, H. (2014). Transgenic Efficiency of FoxN1-targeted Pig 
Parthenogenetic Embryos. J. Embryo Transfer 29, 339-344.

Jansen, R., Embden, J.D.A.v., Gaastra, W., and Schouls, L.M. (2002). Identification of genes that are associated with DNA repeats in prokaryotes. Mol. Microbiol. 43, 1565-1575.

Jia, H., and Wang, N. (2014). Targeted Genome Editing of Sweet Orange Using Cas9/sgRNA. PLoS ONE 9, e93806.

Jiang, W., Zhou, H., Bi, H., Fromm, M., Yang, B., and Weeks, D.P. (2013). Demonstration of CRISPR/Cas9/sgRNA-mediated targeted gene modification in Arabidopsis, tobacco, sorghum and rice. Nucleic Acids Res. 41, e188.

Khan, M., Naeem, M., and Iqbal, M. (2014). Breeding approaches for bacterial leaf blight resistance in rice (Oryza sativa L.), current status and future directions. Eur. J. Plant Pathol. 139, 27-37.

Klymiuk, N., Fezert, P., Wünsch, A., Kurome, M., Kessler, B., and Wolf, E. (2014). Homologous recombination contributes to the repair of zincfinger-nuclease induced double strand breaks in pig primary cells and facilitates recombination with exogenous DNA. J. Biotechnol. 177, 74-81.

Koo, O.J., Park, S.J., Lee, C., Kang, J.T., Kim, S., Moon, J.H., Choi, J.Y., Kim, H., Jang, G., Kim, J.-S., et al. (2014). Production of Mutated Porcine Embryos Using Zinc Finger Nucleases and a Reporter-based Cell Enrichment System. Asian-Australas. J. Anim. Sci. 27, 324-329.

Kumar, S., AlAbed, D., Worden, A., Novak, S., Wu, H., Ausmus, C., Beck, M., Robinson, H., Minnicks, T., Hemingway, D., et al. (2015). A modular gene targeting system for sequential transgene stacking in plants. J. Biotechnol. 207, 12-20.

Kwon, D.-N., Lee, K., Kang, M.-J., Choi, Y.-J., Park, C., Whyte, J.J., Brown, A.N., Kim, J.-H., Samuel, M., Mao, J., et al. (2013). Production of biallelic CMP-Neu5Ac hydroxylase knockout pigs. Sci. Rep. 3.

Ledford, H. (2013). US regulation misses some GM crops. Nature 500, 389-390.

Ledford, H. (2015). CRISPR, the disruptor. Nature 522, 20-24.

Lee, S., Park, H., Kong, I., and Wang, Z. (2014). A transcription activator-like effector nuclease (talen)-mediated universal gene knock-in strategy for mammary glands-specific expression of recombinant proteins in dairy cattle. Reprod. Fertil. Dev. 26, 129.
Li, D., Qiu, Z., Shao, Y., Chen, Y., Guan, Y., Liu, M., Li, Y., Gao, N., Wang, L., Lu, X., et al. (2013a). Heritable gene targeting in the mouse and rat using a CRISPR-Cas system. Nat. Biotechnol. 31, 681-683.

Li, F., Li, Y., Liu, H., Zhang, H., Liu, C., Zhang, X., Dou, H., Yang, W., and Du, Y. (2014a). Production of GHR double-allelic knockout Bama pig by TALENs and handmade cloning. Yi Chuan 36, 903-911.

Li, J.-F., Norville, J.E., Aach, J., McCormack, M., Zhang, D., Bush, J., Church, G.M., and Sheen, J. (2013b). Multiplex and homologous recombination-mediated genome editing in Arabidopsis and Nicotiana benthamiana using guide RNA and Cas9. Nat. Biotechnol. 31, 688-691.

Li, M., Yang, H., Zhao, J., Fang, L., Shi, H., Li, M., Sun, Y., Zhang, X., Jiang, D., Zhou, L., et al. (2014b). Efficient and Heritable Gene Targeting in Tilapia by CRISPR/Cas9. Genetics 197, 591-599.

Li, P., Estrada, J.L., Burlak, C., Montgomery, J., Butler, J.R., Santos, R.M., Wang, Z.-Y., Paris, L.L., Blankenship, R.L., Downey, S.M., et al. (2015). Efficient generation of genetically distinct pigs in a single pregnancy using multiplexed single-guide RNA and carbohydrate selection. Xenotransplantation 22, 20-31.

Li, P., Estrada, J.L., Burlak, C., and Tector, A.J. (2013c). Biallelic knockout of the $\alpha-1,3$ galactosyltransferase gene in porcine liverderived cells using zinc finger nucleases. J. Surg. Res. 181, e39-e45.

Li, T., Liu, B., Spalding, M.H., Weeks, D.P., and Yang, B. (2012). High-efficiency TALEN-based gene editing produces disease-resistant rice. Nat. Biotechnol. 30, 390-392.

Liang, Z., Zhang, K., Chen, K., and Gao, C. (2014). Targeted Mutagenesis in Zea mays Using TALENs and the CRISPR/Cas System. J. Genet. Genomics 41, 63-68.

Lillico, S.G., Proudfoot, C., Carlson, D.F., Stverakova, D., Neil, C., Blain, C., King, T.J., Ritchie, W.A., Tan, W., Mileham, A.J., et al. (2013). Live pigs produced from genome edited zygotes. Sci. Rep. 3.

Liu, J., Li, C., Yu, Z., Huang, P., Wu, H., Wei, C., Zhu, N., Shen, Y., Chen, Y., Zhang, B., et al. (2012). Efficient and Specific Modifications of the Drosophila Genome by Means of an Easy TALEN Strategy. J. Genet. Genomics 39, 209-215. 
Liu, W., Yuan, J.S., and Stewart Jr, C.N. (2013). Advanced genetic tools for plant biotechnology. Nat. Rev. Genet. 14, 781-793.

Liu, X., Wang, Y., Tian, Y., Yu, Y., Gao, M., Hu, G., Su, F., Pan, S., Luo, Y., Guo, Z., et al. (2014). Generation of mastitis resistance in cows by targeting human lysozyme gene to $\beta$ casein locus using zinc-finger nucleases. Proc. R. Soc. London B 281, 20133368.

Lor, V.S., Starker, C.G., Voytas, D.F., Weiss, D., and Olszewski, N.E. (2014). Targeted Mutagenesis of the Tomato PROCERA Gene Using Transcription Activator-Like Effector Nucleases. Plant Physiol. 166, 1288-1291.

Luo, J., Song, Z., Yu, S., Cui, D., Wang, B., Ding, F., Li, S., Dai, Y., and Li, N. (2014). Efficient Generation of Myostatin (MSTN) Biallelic Mutations in Cattle Using Zinc Finger Nucleases. PLoS ONE 9, e95225.

Lusser, M., and Davies, H.V. (2013). Comparative regulatory approaches for groups of new plant breeding techniques. N. Biotechnol. 30, 437-446.

Marton, I., Zuker, A., Shklarman, E., Zeevi, V., Tovkach, A., Roffe, S., Ovadis, M., Tzfira, T., and Vainstein, A. (2010). Nontransgenic Genome Modification in Plant Cells. Plant Physiol. 154, 1079-1087.

Miao, J., Guo, D., Zhang, J., Huang, Q., Qin, G., Zhang, X., Wan, J., Gu, H., and Qu, L.-J. (2013). Targeted mutagenesis in rice using CRISPR-Cas system. Cell Res. 23, 1233-1236.

Mikami, M., Toki, S., and Endo, M. (2015). Comparison of CRISPR/Cas9 expression constructs for efficient targeted mutagenesis in rice. Plant Mol. Biol. 88, 561-572.

Moghaddassi, S., Eyestone, W., and Bishop, C.E. (2014). TALEN-Mediated Modification of the Bovine Genome for Large-Scale Production of Human Serum Albumin. PLoS ONE 9, e89631.

Naito, Y., Hino, K., Bono, H., and Ui-Tei, K. (2014). CRISPRdirect: software for designing CRISPR/Cas guide RNA with reduced offtarget sites. Bioinformatics 31, 1120-1123.

Ni, W., Qiao, J., Hu, S., Zhao, X., Regouski, M., Yang, M., Polejaeva, I.A., and Chen, C. (2014). Efficient gene knockout in goats using CRISPR/Cas9 system. PLoS ONE 9, e106718.

Nicolia, A., Proux-Wéra, E., Åhman, I., Onkokesung, N., Andersson, M., Andreasson, E., and Zhu, L.-H. (2015). Targeted gene mutation in tetraploid potato through transient
TALEN expression in protoplasts. J. Biotechnol. 204, 17-24.

Notarnicola, B., Hayashi, K., Curran, M.A., and Huisingh, D. (2012). Progress in working towards a more sustainable agri-food industry. J. Cleaner. Prod. 28, 1-8.

Osusky, M., Zhou, G., Osuska, L., Hancock, R.E., Kay, W.W., and Misra, S. (2000). Transgenic plants expressing cationic peptide chimeras exhibit broad-spectrum resistance to phytopathogens. Nat. Biotechnol. 18, 1162-1166.

Ousterout, D.G., Kabadi, A.M., Thakore, P.I., Perez-Pinera, P., Brown, M.T., Majoros, W.H., Reddy, T.E., and Gersbach, C.A. (2015). Correction of Dystrophin Expression in Cells From Duchenne Muscular Dystrophy Patients Through Genomic Excision of Exon 51 by Zinc Finger Nucleases. Mol. Ther. 23, 523-532.

Ovesná, J., and de Vries, G. (2005). Environmental Issues and Problems Associated with Genetically Modified Organisms. In Genes on the Menu: Facts for Knowledge-Based Decision, P. Pechan, and G. de Vries, eds. (Berlin: Springer Science and Business Media), pp. 61-72.

Ovesná, J., Strymplová Št’astná, K., Vaculová, K., and Milotová, J. (2010). Haplotyping barley bmy1 using the SNaPshot assay. Biologia 65, 75-80.

Park, T.S., Lee, H.J., Kim, K.H., Kim, J.-S., and Han, J.Y. (2014). Targeted gene knockout in chickens mediated by TALENs. Proc. Nat. Acad. Sci. USA 111, 12716-12721.

Peer, R., Rivlin, G., Golobovitch, S., Lapidot, M., Gal-On, A., Vainstein, A., Tzfira, T., and Flaishman, M. (2015). Targeted mutagenesis using zinc-finger nucleases in perennial fruit trees. Planta 241, 941-951.

Peng, J., Wang, Y., Jiang, J., Zhou, X., Song, L., Wang, L., Ding, C., Qin, J., Liu, L., Wang, W., et al. (2015). Production of Human Albumin in Pigs Through CRISPR/Cas9-Mediated Knockin of Human cDNA into Swine Albumin Locus in the Zygotes. Sci. Rep. 5, 16705.

Petersen, B., and Niemann, H. (2015a). Advances in genetic modification of farm animals using zinc-finger nucleases (ZFN). Chromosome Res. 23, 7-15.

Petersen, B., and Niemann, H. (2015b). Molecular scissors and their application in genetically modified farm animals. Transgenic Res. 24, 381-396.

Pimentel, D. (2011). Environmental and economic costs associated with alien invasive 
species in the United States. In Biological Invasions, D. Pimentel, ed. (CRC Press USA), pp. 411-430.

Pimentel, D., and Burgess, M. (2014). Environmental and Economic Costs of the Application of Pesticides Primarily in the United States. In Integrated Pest Management, D. Pimentel, and R. Peshin, eds. (Springer Netherlands), pp. 47-71.

Podevin, N., Devos, Y., Davies, H.V., and Nielsen, K.M. (2012). Transgenic or not? No simple answer! EMBO Rep. 13, 1057-1061.

Privalle, L.S., Chen, J., Clapper, G., Hunst, P., Spiegelhalter, F., and Zhong, C.X. (2012). Development of an Agricultural Biotechnology Crop Product: Testing from Discovery to Commercialization. J. Agric. Food Chem. 60, 10179-10187.

Proudfoot, C., Carlson, D., Huddart, R., Long, C., Pryor, J., King, T., Lillico, S., Mileham, A., McLaren, D., Whitelaw, C.B., et al. (2015). Genome edited sheep and cattle. Transgenic Res. 24, 147-153.

Puchta, H., and Fauser, F. (2014). Synthetic nucleases for genome engineering in plants: prospects for a bright future. Plant J. 78, 727-741.

Qian, L., Tang, M., Yang, J., Wang, Q., Cai, C., Jiang, S., Li, H., Jiang, K., Gao, P., Ma, D., et al. (2015). Targeted mutations in myostatin by zinc-finger nucleases result in double-muscled phenotype in Meishan pigs. Sci. Rep. 5, 14435.

Ribarits, A., Brüller, W., Hartmann, J., Hochegger, R., Mechtler, K., Peterseil, V., Söllinger, J., Stepanek, W., Widhalm, I., and Wögerbauer, M. (2014). Use of novel techniques in plant breeding and practical consequences concerning detection, traceability, labeling, and risk assessment. AgBioForum 17, 183-190.

Rinaldo, A., and Ayliffe, M. (2015). Gene targeting and editing in crop plants: a new era of precision opportunities. Mol. Breed. 35, 1-15.

Ruan, J., Li, H., Xu, K., Wu, T., Wei, J., Zhou, R., Liu, Z., Mu, Y., Yang, S., Ouyang, H., et al. (2015). Highly efficient CRISPR/Cas9mediated transgene knockin at the $\mathrm{H} 11$ locus in pigs. Sci. Rep. 5, 14253.

Semaan, M., Ivanusic, D., and Denner, J. (2015). Cytotoxic Effects during Knock Out of Multiple Porcine Endogenous Retrovirus (PERV) Sequences in the Pig Genome by Zinc Finger Nucleases (ZFN). PLoS ONE 10, e0122059.
Shan, Q., Wang, Y., Chen, K., Liang, Z., Li, J., Zhang, Y., Zhang, K., Liu, J., Voytas, D.F., Zheng, X., et al. (2013a). Rapid and Efficient Gene Modification in Rice and Brachypodium Using TALENs. Mol. Plant 6, 1365-1368.

Shan, Q., Wang, Y., Li, J., Zhang, Y., Chen, K., Liang, Z., Zhang, K., Liu, J., Xi, J.J., Qiu, J.-L., et al. (2013b). Targeted genome modification of crop plants using a CRISPR-Cas system. Nat. Biotechnol. 31, 686-688.

Shan, Q., Zhang, Y., Chen, K., Zhang, K., and Gao, C. (2015). Creation of fragrant rice by targeted knockout of the OsBADH2 gene using TALEN technology. Plant Biotechnol. J. 13, 791-800.

Shukla, V.K., Doyon, Y., Miller, J.C., DeKelver, R.C., Moehle, E.A., Worden, S.E., Mitchell, J.C., Arnold, N.L., Gopalan, S., Meng, X., et al. (2009). Precise genome modification in the crop species Zea mays using zinc-finger nucleases. Nature 459, 437-441.

Smyth, S.J., McDonald, J., and Falck-Zepeda, J. (2014). Investment, regulation, and uncertainty. GM Crops Food 5, 44-57.

Song, Y., Cui, C., Zhu, H., Li, Q., Zhao, F., and Jin, Y. (2015). Expression, purification and characterization of zinc-finger nuclease to knockout the goat beta-lactoglobulin gene. Protein Expression Purif. 112, 1-7.

Spencer, J.D., Allee, G.L., and Sauber, T.E. (2000). Phosphorus bioavailability and digestibility of normal and genetically modified low-phytate corn for pigs. J. Anim. Sci. 78, 675-681.

Sun, X., Hu, Z., Chen, R., Jiang, Q., Song, G., Zhang, H., and Xi, Y. (2015). Targeted mutagenesis in soybean using the CRISPRCas9 system. Sci. Rep. 5.

Sun, Z., Li, N., Huang, G., Xu, J., Pan, Y., Wang, Z., Tang, Q., Song, M., and Wang, X. (2013). Site-Specific Gene Targeting Using Transcription Activator-Like Effector (TALE)Based Nuclease in Brassica oleracea. J. Integr. Plant Biol. 55, 1092-1103.

Tan, W., Carlson, D.F., Lancto, C.A., Garbe, J.R., Webster, D.A., Hackett, P.B., and Fahrenkrug, S.C. (2013). Efficient nonmeiotic allele introgression in livestock using custom endonucleases. Proc. Nat. Acad. Sci. USA 110, 16526-16531.

Tesson, L., Usal, C., Menoret, S., Leung, E., Niles, B.J., Remy, S., Santiago, Y., Vincent, A.l., Meng, X., Zhang, L., et al. (2011). Knockout rats generated by embryo 
microinjection of TALENs. Nat. Biotechnol. 29, 695-696.

Upadhyay, S.K., Kumar, J., Alok, A., and Tuli, R. (2013). RNA-Guided Genome Editing for Target Gene Mutations in Wheat. G3 (Bethesda) 3, 2233-2238.

Urnov, F.D., Rebar, E.J., Holmes, M.C., Zhang, H.S., and Gregory, P.D. (2010). Genome editing with engineered zinc finger nucleases. Nat. Rev. Genet. 11, 636-646.

Van Boxstael, S., Habib, I., Jacxsens, L., De Vocht, M., Baert, L., Van De Perre, E., Rajkovic, A., Lopez-Galvez, F., Sampers, I., Spanoghe, P., et al. (2013). Food safety issues in fresh produce: Bacterial pathogens, viruses and pesticide residues indicated as major concerns by stakeholders in the fresh produce chain. Food Control 32, 190-197.

Véron, N., Qu, Z., Kipen, P.A.S., Hirst, C.E., and Marcelle, C. (2015). CRISPR mediated somatic cell genome engineering in the chicken. Dev. Biol. 407, 68-74.

Voytas, D.F. (2013). Plant Genome Engineering with Sequence-Specific Nucleases. Annu. Rev. Plant. Biol. 64, 327-350.

Wang, K., Ouyang, H., Xie, Z., Yao, C., Guo, N., Li, M., Jiao, H., and Pang, D. (2015a). Efficient Generation of Myostatin Mutations in Pigs Using the CRISPR/Cas9 System. Sci. Rep. 5, 16623.

Wang, S., Zhang, S., Wang, W., Xiong, X., Meng, F., and Cui, X. (2015b). Efficient targeted mutagenesis in potato by the CRISPR/Cas9 system. Plant Cell Reports 34, 1473-1476.

Wang, X., Yu, H., Lei, A., Zhou, J., Zeng, W., Zhu, H., Dong, Z., Niu, Y., Shi, B., Cai, B., et al. (2015c). Generation of gene-modified goats targeting MSTN and FGF5 via zygote injection of CRISPR/Cas9 system. Sci. Rep. 5, 13878.

Wang, X., Zhou, J., Cao, C., Huang, J., Hai, T., Wang, Y., Zheng, Q., Zhang, H., Qin, G., Miao, $X$. et al. (2015d). Efficient CRISPR/Cas9mediated biallelic gene disruption and sitespecific knockin after rapid selection of highly active sgRNAs in pigs. Sci. Rep. 5, 13348.

Wang, Y., Du, Y., Shen, B., Zhou, X., Li, J., Liu, Y., Wang, J., Zhou, J., Hu, B., Kang, N., et al. (2015e). Efficient generation of gene-modified pigs via injection of zygote with Cas9/sgRNA. Sci. Rep. 5.

Wang, Y., Cheng, X., Shan, Q., Zhang, Y., Liu, J., Gao, C., and Qiu, J.-L. (2014). Simultaneous editing of three homoeoalleles in hexaploid bread wheat confers heritable resistance to powdery mildew. Nat. Biotechnol. 32, 947-951.

Watanabe, M., Nakano, K., Matsunari, H., Matsuda, T., Maehara, M., Kanai, T., Kobayashi, M., Matsumura, Y., Sakai, R., Kuramoto, M., et al. (2013). Generation of Interleukin-2 Receptor Gamma Gene Knockout Pigs from Somatic Cells Genetically Modified by Zinc Finger Nuclease-Encoding mRNA. PLoS ONE 8, e76478.

Watanabe, M., Umeyama, K., Matsunari, H., Takayanagi, S., Haruyama, E., Nakano, K., Fujiwara, T., Ikezawa, Y., Nakauchi, H., and Nagashima, H. (2010). Knockout of exogenous EGFP gene in porcine somatic cells using zinc-finger nucleases. Biochem. Biophys. Res. Commun. 402, 14-18.

Wei, J., Wagner, S., Lu, D., Maclean, P., Carlson, D.F., Fahrenkrug, S.C., and Laible, G. (2015). Efficient introgression of allelic variants by embryo-mediated editing of the bovine genome. Sci. Rep. 5, 11735.

Wendt, T., Holm, P., Starker, C., Christian, M., Voytas, D., Brinch-Pedersen, H., and Holme, I. (2013). TAL effector nucleases induce mutations at a pre-selected location in the genome of primary barley transformants. Plant Mol. Biol. 83, 279-285.

White, P.J., and Brown, P.H. (2010). Plant nutrition for sustainable development and global health. Ann. Bot. 105, 1073-1080.

Whitworth, K.M., Lee, K., Benne, J.A., Beaton, B.P., Spate, L.D., Murphy, S.L., Samuel, M.S., Mao, J., O'Gorman, C., Walters, E.M., et al. (2014). Use of the CRISPR/Cas9 System to Produce Genetically Engineered Pigs from In Vitro-Derived Oocytes and Embryos. Biol. Reprod. 91, 78, 71-13.

Whyte, J.J., Zhao, J., Wells, K.D., Samuel, M.S., Whitworth, K.M., Walters, E.M., Laughlin, M.H., and Prather, R.S. (2011). Gene targeting with zinc finger nucleases to produce cloned eGFP knockout pigs. Mol. Reprod. Dev. 78, 2.

Woo, J.W., Kim, J., Kwon, S.I., Corvalan, C., Cho, S.W., Kim, H., Kim, S.-G., Kim, S.-T., Choe, S., and Kim, J.-S. (2015). DNA-free genome editing in plants with preassembled CRISPR-Cas9 ribonucleoproteins. Nat. Biotechnol. 33, 1162-1164.

Xie, K., and Yang, Y. (2013). RNA-Guided Genome Editing in Plants Using a CRISPRCas System. Mol. Plant 6, 1975-1983.

Xie, S., Shen, B., Zhang, C., Huang, X., and Zhang, Y. (2014). sgRNAcas9: A Software Package for Designing CRISPR sgRNA and 
Evaluating Potential Off-Target Cleavage Sites. PLoS ONE 9, e100448.

Xin, J., Yang, H., Fan, N., Zhao, B., Ouyang, Z., Liu, Z., Zhao, Y., Li, X., Song, J., Yang, Y., et al. (2013). Highly Efficient Generation of GGTA1 Biallelic Knockout Inbred Mini-Pigs with TALENs. PLoS ONE 8, e84250.

Xiong, K., Li, S., Zhang, H., Cui, Y., Yu, D., Li, Y., Sun, W., Fu, Y., Teng, Y., Liu, Z., et al. (2013). Targeted editing of goat genome with modularassembly zinc finger nucleases based on activity prediction by computational molecular modeling. Mol. Biol. Rep. 40, 4251-4256.

Xu, R.-F., Li, H., Qin, R.-Y., Li, J., Qiu, C.-H., Yang, Y.-C., Ma, H., Li, L., Wei, P.-C., and Yang, J.-B. (2015). Generation of inheritable and "transgene clean" targeted genomemodified rice in later generations using the CRISPR/Cas9 system. Sci. Rep. 5.

Xu, R., Li, H., Qin, R., Wang, L., Li, L., Wei, P., and Yang, J. (2014). Gene targeting using the Agrobacterium tumefaciens-mediated CRISPR-Cas system in rice. Rice 7, 1-4.

Yang, D., Yang, H., Li, W., Zhao, B., Ouyang, Z., Liu, Z., Zhao, Y., Fan, N., Song, J., Tian, J., et al. (2011). Generation of PPARy mono-allelic knockout pigs via zinc-finger nucleases and nuclear transfer cloning. Cell Res. 21, 979-982.

Yano, A., Nicol, B., Jouanno, E., and Guiguen, Y. (2014). Heritable Targeted Inactivation of the Rainbow Trout (Oncorhynchus mykiss) Master Sex-Determining Gene Using Zinc-Finger Nucleases. Mar. Biotechnol. 16, 243-250.

Yao, J., Huang, J., Hai, T., Wang, X., Qin, G., Zhang, H., Wu, R., Cao, C., Xi, J.J., Yuan, Z., et al. (2014). Efficient bi-allelic gene knockout and site-specific knock-in mediated by TALENs in pigs. Sci. Rep. 4.
Yu, S., Luo, J., Song, Z., Ding, F., Dai, Y., and Li, N. (2011). Highly efficient modification of betalactoglobulin (BLG) gene via zinc-finger nucleases in cattle. Cell Res. 21, 1638-1640.

Zhang, C., Wang, L., Ren, G., Li, Z., Ren, C., Zhang, T., Xu, K., and Zhang, Z. (2014a). Targeted disruption of the sheep MSTN gene by engineered zinc-finger nucleases. Mol. Biol. Rep. 41, 209-215.

Zhang, H., Zhang, J., Wei, P., Zhang, B., Gou, F., Feng, Z., Mao, Y., Yang, L., Zhang, H., Xu, N., et al. (2014b). The CRISPR/Cas9 system produces specific and homozygous targeted gene editing in rice in one generation. Plant Biotechnol. J. 12, 797-807.

Zhang, Y., Zhang, F., Li, X., Baller, J.A., Qi, Y., Starker, C.G., Bogdanove, A.J., and Voytas, D.F. (2013). Transcription Activator-Like Effector Nucleases Enable Efficient Plant Genome Engineering. Plant Physiol. 161, 20-27.

Zhou, H., Liu, B., Weeks, D.P., Spalding, M.H., and Yang, B. (2014). Large chromosomal deletions and heritable small genetic changes induced by CRISPR/Cas9 in rice. Nucleic Acids Res. 42, 10903-10914.

Zhou, X., Xin, J., Fan, N., Zou, Q., Huang, J., Ouyang, Z., Zhao, Y., Zhao, B., Liu, Z., Lai, S., et al. (2015). Generation of CRISPR/Cas9mediated gene-targeted pigs via somatic cell nuclear transfer. Cell. Mol. Life. Sci. 72, $1175-1184$.

Zu, Y., Tong, X., Wang, Z., Liu, D., Pan, R., Li, Z., $\mathrm{Hu}$, Y., Luo, Z., Huang, P., Wu, Q., et al. (2013). TALEN-mediated precise genome modification by homologous recombination in zebrafish. Nat. Methods 10, 329-331. 


\section{Microbiology / Molecular Biology}

Caister Academic Press is a leading academic publisher of advanced texts in microbiology, molecular biology and medical research. Full details of all our publications at caister.com

- Cyanobacteria: Omics and Manipulation Edited by: DA Los (2017) www.caister.com/cyano3

- Brain-eating Amoebae: Biology and Pathogenesis of Naegleria fowleri

Author: R Siddiqui, IKM Ali, JR Cope, et al. (2016)

"explains the current knowledge and research" (ProtoView) www.caister.com/naegleria

- Foot and Mouth Disease Virus: Current Research and Emerging Trends

Edited by: F Sobrino, E Domingo (2017)

www.caister.com/fmdv

- Staphylococcus: Genetics and Physiology

Edited by: GA Somerville (2016)

www.caister.com/staph2

- Chloroplasts: Current Research and Future Trends Edited by: H Kirchhoff (2016)

www.caister.com/chloroplasts

- Microbial Biodegradation: From Omics to Function and Application

Edited by: J Długoński (2016)

www.caister.com/biodegradation

- Influenza: Current Research

Edited by: Q Wang, YJ Tao (2016)

www.caister.com/flu3

- MALDI-TOF Mass Spectrometry in Microbiology Edited by: M Kostrzewa, S Schubert (2016)

www.caister.com/malditof

- Aspergillus and Penicillium in the Post-genomic Era Edited by: RP Vries, IB Gelber, MR Andersen (2016)

"new and well-presented book" (IMA Fungus)

www.caister.com/aspergillus2

- The Bacteriocins: Current Knowledge and Future

Prospects

Edited by: RL Dorit, SM Roy, MA Riley (2016)

www.caister.com/bacteriocins

- Omics in Plant Disease Resistance

Edited by: V Bhadauria (2016)

"essential reading ... highly recommended" (Biotechnol. Agron.

Soc. Environ.)

www.caister.com/opdr

- Acidophiles: Life in Extremely Acidic Environments

Edited by: R Quatrini, DB Johnson (2016)

"Contributors from a wide range of biological and environmental sciences" (ProtoView)

www.caister.com/acidophiles
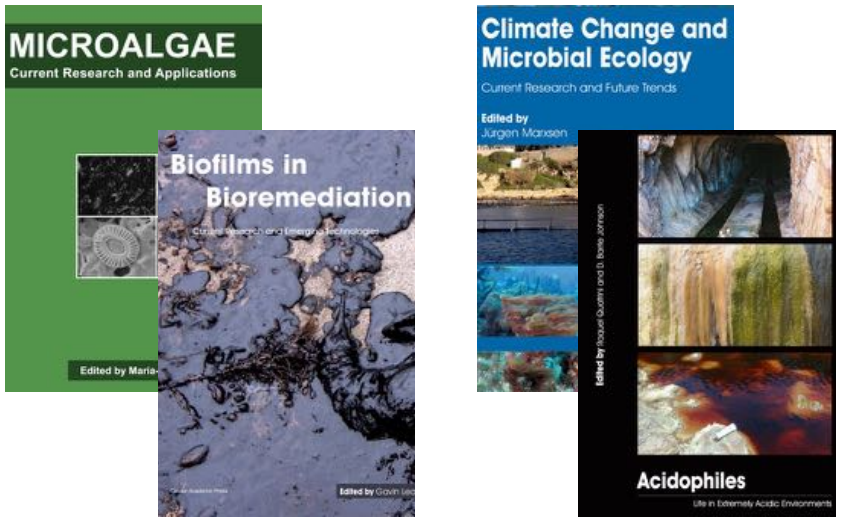
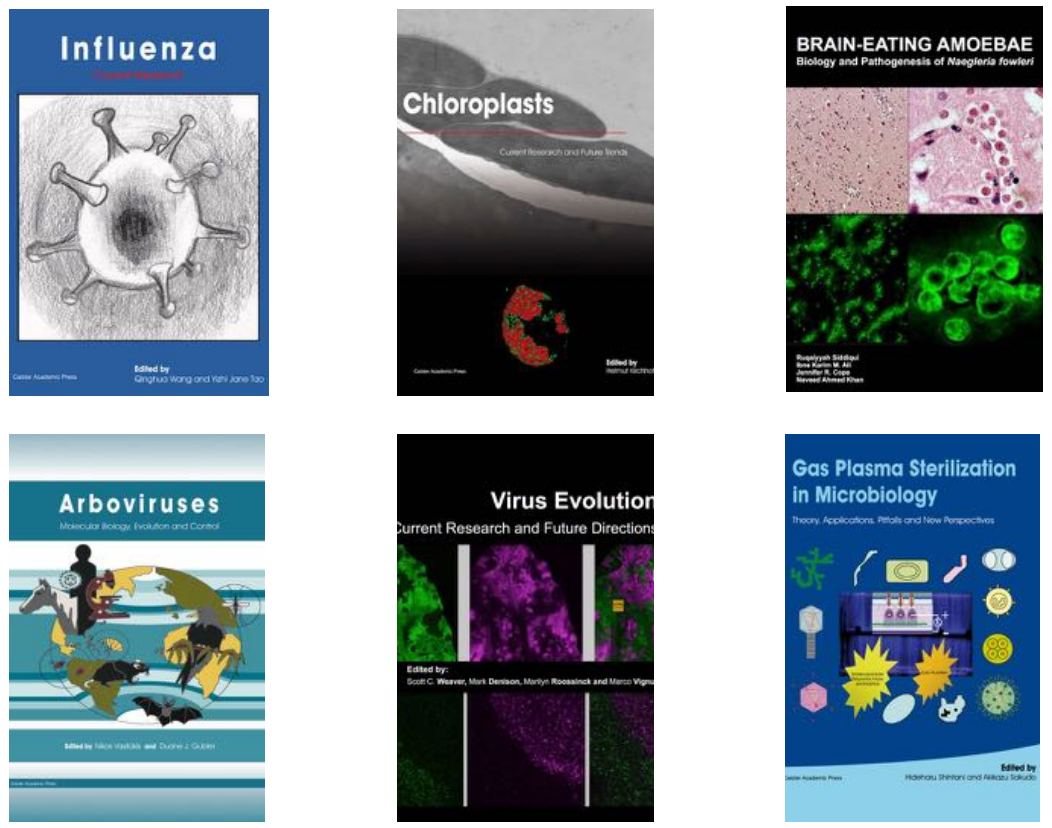

- Climate Change and Microbial Ecology: Current Research and Future Trends

Edited by: J Marxsen (2016)

"impressive" (ASM: Small Things Considered); "written at a high scientific level" (BioSpektrum)

www.caister.com/climate

- Biofilms in Bioremediation: Current Research and Emerging Technologies

Edited by: G Lear (2016)

"describes explicitly the role of biofilms in bioremediation" (Biospektrum); indispensable ... recommended (Biotechnol. Agron. Soc. Environ.) www.caister.com/biorem

- Microalgae: Current Research and Applications

Edited by: MN Tsaloglou (2016)

www.caister.com/microalgae

- Gas Plasma Sterilization in Microbiology: Theory, Applications, Pitfalls and New Perspectives

Edited by: H Shintani, A Sakudo (2016)

"a nice state of the art compilation" (Doodys)

www.caister.com/gasplasma

- Virus Evolution: Current Research and Future Directions Edited by: SC Weaver, M Denison, M Roossinck, et al. (2016) "highly informative ... a pleasure to read" (Microbiol. Today) www.caister.com/virusevol

- Arboviruses: Molecular Biology, Evolution and Control Edited by: N Vasilakis, DJ Gubler (2016)

"a thorough and compelling review ... an outstanding book ... highly recommended" (Am. J. Trop. Med. Hyg.) www.caister.com/arbo

- Shigella: Molecular and Cellular Biology

Edited by: WD Picking, WL Picking (2016)

www.caister.com/shigella

- Aquatic Biofilms: Ecology, Water Quality and Wastewater Treatment

Edited by: AM Romaní, H Guasch, MD Balaguer (2016)

"essential reference book" (Biotechnol. Agron. Soc. Environ.)

www.caister.com/aquaticbiofilms

- Alphaviruses: Current Biology

Edited by: S Mahalingam, L Herrero, B Herring (2016)

"up-to-date review of the field" (Aus. Vet. J.)

www.caister.com/alpha 